\title{
Morphology-Dependent Enhancement of Arsenite Oxidation to Arsenate on Birnessite-Type Manganese Oxide
}

by Jingtao Hou, J., Xiang, Y., Zheng D., Li Y., Xue, S., Wu, C., Hartley, W. and Tan, W.

Copyright, Publisher and Additional Information: This is the author accepted manuscript. The final published version (version of record) is available online via University of California Press Please refer to any applicable terms of use of the publisher.

DOI: https://doi.org/10.1016/j.cej.2017.06.102 


\section{Morphology-Dependent Enhancement of Arsenite Oxidation to Arsenate on}

\section{Birnessite-Type Manganese Oxide}

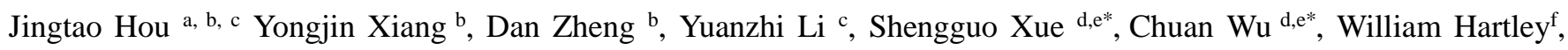
Wenfeng $\operatorname{Tan}^{\mathrm{a}}$

${ }^{\text {a }}$ College of Resources and Environment, Huazhong Agricultural University, Wuhan, 430070, China.

b School of Environmental and Biological Engineering, Wuhan Technology and Business University, Wuhan, 430065, China.

${ }^{c}$ State Key Laboratory of Silicate Materials for Architectures Wuhan University of Technology, Wuhan, 430070, China.

d Department of Environmental Engineering, School of Metallurgy and Environment, Central South University, Changsha, 410083, China.

e Chinese National Engineering Research Centre for Control and Treatment of Heavy Metal Pollution, Changsha 410083, China

${ }^{\mathrm{f}}$ Crop and Environment Sciences Department, Harper Adams University, Newport, Shropshire, TF10 8NB, United Kingdom

Corresponding author:

* Email: sgxue70@hotmail.com (S. G. Xue), wuchuan@csu.edu.cn (C.Wu). 


\section{Abstract:}

Birnessite-type manganese oxide is a highly efficient oxidant that has been investigated widely for As(III) oxidation. Nevertheless, As(III) oxidation rate is inevitably reduced due to favorable adsorption of coexisting ions and As(V) which passivate its surface. In this paper we explore a novel strategy to significantly improve As(III) oxidation rate by controlling birnessite morphology. Batch investigations revealed that As(III) oxidation was greatly improved with nanoflower-like birnessite (Bir-NF) compared to nanowire- (Bir-NW) and nanosheet-like (Bir-NS) birnessites. Changing birnessite morphology from nanosheet to nanoflower not only improved As(III) oxidation rate, from 1.4 to $24.7 \mu \mathrm{mol} \mathrm{g}^{-1} \mathrm{~min}^{-1}$, but also reduced the antagonistic effects of $\mathrm{As}(\mathrm{V})$ and coexisting ion adsorption on As(III) removal. The origin of morphology-dependent enhancement of As(III) removal was experimentally and theoretically studied by $\mathrm{As}(\mathrm{V})$ adsorption on birnessites, phosphate adsorption kinetics, detection of dissolved $\mathrm{Mn}^{2+}$ concentration, average Mn oxidation state, point of zero charge, and density functional theory (DFT) calculations. Results revealed that significant enhancement of As(III) oxidation activity in Bir-NF was attributed to its highly efficient contact between As(III) species and manganese oxide, as well as the rapid charge transfer from As to Mn atom due to its highest oxygen vacancy defect concentration, thus significantly promoting As(III) oxidation activity.

Keywords: Morphology; Birnessite-type manganese oxide; Arsenite; Arsenate; Oxidation; Competitive adsorption. 


\section{Introduction}

Arsenic (As) is one of the most common environmental pollutants and can exist in four oxidation states, arsine (-3), arsenic (0), arsenite (+3), and arsenate (+5). Arsenite $[\mathrm{As}(\mathrm{III})]$ and arsenate $[\mathrm{As}(\mathrm{V})]$ are the two main inorganic arsenic species that are found in arsenic-containing wastewater. Arsenite has greater toxicity, but a weaker affinity for adsorbents than $\mathrm{As}(\mathrm{V})$. The preoxidation of $\mathrm{As}(\mathrm{III})$ to $\mathrm{As}(\mathrm{V})$ is regarded as a critical process for decreasing As toxicity and improving total As removal using treatment methods such as adsorption and co-precipitation $[1,2]$. To date, a large number of chemical oxidants have been developed for highly efficient oxidation of As(III) to As(V), and include ozone [3], chlorine [4] and hydrogen peroxide [2,5,6]. Nevertheless, these oxidants are not environmentally friendly, producing toxic byproducts [7], and therefore it is highly desirable to explore other alternatives [8].

Birnessite is a type of manganese oxide that has a two-dimensional (2D) layer structure of edge-shared $\mathrm{MnO}_{6}$ octahedra with exchangeable ions (e.g. $\mathrm{Na}^{+}, \mathrm{K}^{+}$) and $\mathrm{H}_{2} \mathrm{O}$ molecules inside the interlayer [9]. Because of its high redox potential, birnessite-type manganese oxide has been widely investigated as a highly efficient oxidant for preoxidation of $\mathrm{As}(\mathrm{III})$ to $\mathrm{As}(\mathrm{V})$ [10-14]. It is well known that oxidation of $\mathrm{As}(\mathrm{III})$ to $\mathrm{As}(\mathrm{V})$ by manganese oxide couples with adsorption of $\mathrm{As}(\mathrm{V})$ [14,15]. Experimental and theoretical evidence demonstrates that $\mathrm{As}(\mathrm{V})$ adsorption is more favorable than As(III) on manganese oxide surfaces [14-16]. This means that passivation of manganese oxide surfaces originating from adsorption of $\mathrm{As}(\mathrm{V})$ is inevitable, and may lead to a decrease in $\mathrm{As}(\mathrm{III})$ oxidation [12,17]. In addition, coexisting ions such as phosphate and $\mathrm{Mn}^{2+}$ readily occupy its surface active sites and prevent As(III) binding, thereby reducing the extent and rate of As(III) oxidation [17,18]. A novel approach is required to enhance As(III) oxidation whilst reducing the negative effects of $\mathrm{As}(\mathrm{V})$ and coexisting ions. Yin et al. for example synthesized nanostructured Codoped birnessite through substitution of framework Mn ions with Co [19]. They discovered that the Co-doped birnessite revealed greater As(III) oxidation activity than without doping. This effect was attributed to the higher standard redox potential of $\mathrm{Co}^{3+} / \mathrm{Co}^{2+}$ as compared to that of $\mathrm{MnO}_{2} / \mathrm{Mn}^{2+}$. Villalobos et al. prepared acid birnessite with low specific surface area (SSA) and high vacancy content [20]. They confirmed that As(III) oxidation rate per unit surface area of the acid birnessite sample was greater than that with high SSA and low vacancy content at pH 6. 
The process of controlling birnessite morphology to improve its electrochemical and magnetic properties and catalytic oxidation and purification of environmental pollutants, has attracted much attention [21-23]. For example, in previous work, we compared the catalytic activity of birnessite with nanoflower, nanowire and nanosheet morphologies, and observed that nanoflower-like birnessite showed significant catalytic activity for benzene oxidation compared to nanowire-like and nanosheet-like birnessites [23]. Nevertheless, there are no reports in the literature as to the effect of birnessite morphology on the oxidation of As(III) to As(V). Here, nanoflower (Bir-NF), nanowire (Bir-NW) and nanosheet (Bir-NS) birnessite morphologies were used to oxidize As(III) to As(V). For the first time, we observed the morphology-dependent enhancement of As(III) oxidation activity by birnessite. Compared to Bir-NW and Bir-NS, BirNF not only had the greatest As(III) oxidation rate, but also resisted the adverse effect of $\mathrm{As}(\mathrm{V})$ and coexisting ions on As(III) removal. We combine both experimental and theoretical evidence to reveal the origin of morphology-dependent enhancement of As(III) oxidation by birnessite.

\section{Experimental section}

\subsection{Sample preparation}

Nanoflower-like birnessite was prepared by a facile hydrothermal reaction between $\mathrm{Mn}\left(\mathrm{NO}_{3}\right)_{2}(50$ wt $\%)$ and $\mathrm{KMnO}_{4}$ with $\mathrm{Mn}\left(\mathrm{NO}_{3}\right)_{2} / \mathrm{KMnO}_{4}$ molar ratio of 2 at $50^{\circ} \mathrm{C}$ for $48 \mathrm{~h}$ as described in our previous work [23]. Nanowire-like birnessite was prepared by a hydrothermal reaction between $\mathrm{MnSO}_{4}(0.11 \mathrm{~g})$ and $\mathrm{KMnO}_{4}(0.6 \mathrm{~g})$ at $240{ }^{\circ} \mathrm{C}$ for $24 \mathrm{~h}$ as described in the literature reported by Liang et al [24]. The nanosheet-like birnessite sample was prepared via a facile hydrothermal reaction with $\mathrm{KMnO}_{4}(0.948 \mathrm{~g})$ at $240{ }^{\circ} \mathrm{C}$ for $24 \mathrm{~h}$ as described in the literature reported by Duan et al [22].

\subsection{Batch experimental procedures}

Batch experiments were performed in an oscillating waterbath at a velocity of $160 \mathrm{rpm}$ at $25{ }^{\circ} \mathrm{C}$. Arsenite stock solution $\left(10 \mathrm{mmol} \mathrm{L}^{-1}\right)$ was prepared by dissolving $0.8 \mathrm{~g} \mathrm{NaAsO}_{2}$ into distilled water $(100 \mathrm{~mL})$. The simulated $\mathrm{As}(\mathrm{III})$ wastewater $\left(0.1 \mathrm{mmol} \mathrm{L}^{-1}\right)$ was obtained by a stepwise dilution of $\mathrm{NaAsO}_{2}$ stock solution using a buffer solution $(\mathrm{pH}$ 6.0). Details of the batch experimental procedures are as follows:

Birnessite $(0.05 \mathrm{~g})$ was added to a $0.1 \mathrm{mmol} \mathrm{L}^{-1} \mathrm{As}(\mathrm{III})$ solution $(50 \mathrm{~mL})$. During the period of As(III) oxidation, suspensions $(2.0 \mathrm{~mL})$ were pipetted into a centrifuge tube $(10 \mathrm{~mL})$ at specific intervals, diluted to $8.0 \mathrm{~mL}$ with distilled 
water, and centrifuged at $5000 \mathrm{rpm}$ for $10 \mathrm{~min}$. To investigate the effect of coexisting $\mathrm{As}(\mathrm{V})$, phosphate, and $\mathrm{Mn}^{2+}$ on As(III) removal, $0.1 \mathrm{mmol} \mathrm{L} \mathrm{L}^{-1} \mathrm{NaH}_{2} \mathrm{AsO}_{4} \cdot 7 \mathrm{H}_{2} \mathrm{O}, \mathrm{NaH}_{2} \mathrm{PO}_{4}$, and $\mathrm{Mn}\left(\mathrm{NO}_{3}\right)_{2}$ were respectively added into the initial As(III) solution. The effect of $\mathrm{NaH}_{2} \mathrm{PO}_{4}$ and $\mathrm{Mn}\left(\mathrm{NO}_{3}\right)_{2}$ on $\mathrm{As}(\mathrm{III})$ removal was performed by respectively adding 0.1 , 1.0 , and $10 \mathrm{mmol} \mathrm{L}^{-1}$ into the initial As(III) solution at $\mathrm{pH}$ 6.0. The effect of birnessite dosage was carried out by setting the dosages to $0.2,0.4,0.6,0.8$, and $1.0 \mathrm{~g} \mathrm{~L}^{-1}$ nanoflowers at $\mathrm{pH}$ 6.0. The effect of $\mathrm{pH}$ on As(III) removal was conducted using buffer solutions at $\mathrm{pH}$ 4.7, 6.0 and 9.16, respectively. An acetate acid/sodium acetate buffer system was used for adjusting $\mathrm{pH}$ to 4.7 and 6.0. A sodium carbonate/sodium bicarbonate buffer system was used to adjust $\mathrm{pH}$ to 9.16. $\mathrm{p}$

Preparation details of these buffer solutions are described in previous work [17]. The change in $\mathrm{pH}$ in As solutions was recorded over different reaction periods of $0 \mathrm{~min}, 30 \mathrm{~min}$, and $24 \mathrm{~h}$ using the different buffer systems. $\mathrm{pH}$ had no change during the entire reaction, indicating that the buffer systems used in this work were stable (Fig. S1, Supporting information).

\subsection{Adsorption experiment}

Arsenate adsorption tests were performed using an oscillating waterbath at $160 \mathrm{rpm}, 25{ }^{\circ} \mathrm{C}$. Arsenate $\left(0.1 \mathrm{mmol} \mathrm{L}^{-1}\right)$ was obtained following a stepwise dilution of $\mathrm{NaH}_{2} \mathrm{AsO}_{4} \cdot 7 \mathrm{H}_{2} \mathrm{O}$ stock solution at $\mathrm{pH}$ 6.0. Samples $(0.05 \mathrm{~g})$ were added into $50 \mathrm{~mL}$ of $0.1 \mathrm{mmol} \mathrm{L}^{-1} \mathrm{As}(\mathrm{V})$ in $100 \mathrm{~mL}$ containers. Samples were left for $24 \mathrm{~h}$, then $2.0 \mathrm{~mL}$ aliquots were pipetted into a $10 \mathrm{~mL}$ centrifuge tube, diluted to $8.0 \mathrm{~mL}$ using distilled water, and centrifuged at $5000 \mathrm{rpm}$ for $10 \mathrm{~min}$. The As(V) adsorption capacity of the birnessite samples was calculated as follows:

$$
\mathrm{q}=\mathrm{V}_{\mathrm{o}}\left(\mathrm{C}_{\mathrm{o}}-\mathrm{C}\right) \times 1000 / \mathrm{m}
$$

where $\mathrm{q}$ represents the adsorption capacity of birnessite samples, $\mu$ mol g ${ }^{-1} ; \mathrm{C}_{\mathrm{o}}$ and $\mathrm{C}$ are the initial and residual As(V) and phosphate concentrations after reaction $(24 \mathrm{~h}) ; \mathrm{V}_{0}$ is the solution volume, $\mathrm{L} ; \mathrm{m}$ is the mass of the samples, $\mathrm{g}$.

For adsorption kinetics experiments, birnessite $(0.05 \mathrm{~g})$ was added into $50 \mathrm{~mL}$ of $0.1 \mathrm{mmol} \mathrm{L}^{-1}$ phosphate solution at $\mathrm{pH}$ 6.0. During the period of phosphate adsorption, suspensions $(2.0 \mathrm{~mL})$ were pipetted into a centrifuge tube $(10 \mathrm{~mL})$ at specific intervals, diluted to $8.0 \mathrm{~mL}$ with distilled water, and centrifuged at $5000 \mathrm{rpm}$ for $10 \mathrm{~min}$.

\subsection{Analysis methods}

Total As and $\mathrm{As}(\mathrm{V})$ in solutions were determined by colorimetric spectrophotometry $[17,25]$. Details of analysis 
procedures are described in previous work [17]. When phosphate species were present, As(III) and total As concentrations were determined by atomic absorption spectrophotometry (AAS-6880, SHIMADZU) equipped with hydride generation (LH-2A). Analysis of total $\mathrm{As}$ is described in previous work [17]. Dissolved $\mathrm{Mn}^{2+}$ was also determined using AAS.

\subsection{Characterizaiton}

Birnessite samples, before and after reaction with $0.1 \mathrm{mmol} \mathrm{L}^{-1} \mathrm{As}(\mathrm{III})$, were characterized by a Fourier transform infrared (FTIR) IRAffinity-1S spectrophotometer and a VG Multilab 2000 X-ray photoelectron spectrometer (XPS) using $\mathrm{Mg}$ Ka radiation spectroscopy. Birnessite samples were freeze-dried before characterization.

\subsection{The point of zero charge $\left(\mathrm{pH}_{P Z C}\right)$ analysis}

Birnessite point of zero charge $\left(\mathrm{pH}_{P Z C}\right)$ was measured by salt titration with a prolonged equilibration time according to the literature reported by Tan et al [26]. Measurement procedure details are described in previous work [17]. After adding $\mathrm{KCl}$ into suspension, the Pitzer equation $\left(f_{0.1}=0.77\right)$ was used to eliminate systematic errors. $\mathrm{pH}$ was determined using a pH meter (Model PHS-25, China) with an accuracy of 0.01 .

\subsection{Density functional theory calculation}

Density functional theory (DFT) was used to calculate As adsorption on birnessite surfaces. The Vienna Ab-initio Simulation Package (VASP) software was used to perform DFT calculations. According to XRD data reported in previous work, lattice parameters of birnessite for DFT calculation, obtained from JCPDS 80-1098, were a = 5.149, b = $2.843, c=7.176 \AA, \alpha=\gamma=90^{\circ}, \beta=100.76^{\circ}$. The birnesstie surface plane $\{100\}$ was constructed based on the exposed facet of birnessite observed in HRTEM mapping. As $\mathrm{H}_{2} \mathrm{O}$ molecules can adsorb onto the surface of birnessite, we constructed the planar $\{100\}$ surface with a $\mathrm{H}_{2} \mathrm{O}$ molecule adsorbed, thereby simulating the solution conditions. Details of the calculation are outlined in previous work [17]. A $2 \times 2 \times 2$ Monkhorst-Pack k-point mesh was used for structure optimization. The kinetic cutoff energy was $400 \mathrm{eV}$. Convergence criteria for the electronic and ionic relaxation was $10^{-4} \mathrm{eV}$ and $0.02 \mathrm{eV}^{-1}$, respectively. All calculations were repeated twice to ensure accuracy of the DFT calculation results. 


\section{Results and discussion}

\subsection{Characterization}

Birnessite samples with NF, NW, and NS morphologies were prepared according to the literature reported by Hou et al, Liang et al, and Duan et al, respectively [23,24,27]. Samples were then characterized by XRD, SEM, TEM, ICP-OES, XPS, and $\mathrm{N}_{2}$ adsorption/desorption. XRD patterns revealed that all samples had a pure crystalline birnessite structure (Fig. S2) [23]. Nanoflower and NW samples revealed broader diffraction peaks compared to NS, indicating the presence of smaller crystal sizes in these samples. SEM and TEM images reveal the morphologies of Bir-NF, Bir-NW, and BirNS respectively (Fig. S3) [23]. XPS spectra revealed that only manganese, oxygen, and potassium elements were present in the three samples (Fig. S4). The Mn2p spectra showed that only $\mathrm{Mn}^{3+}$ and $\mathrm{Mn}^{4+}$ species were present in samples, no $\mathrm{Mn}^{2+}$ species were detected [23]. The calculated $\mathrm{Mn}^{3+} / \mathrm{Mn}^{4+}$ ratio in Bir-NF, Bir-NW, and Bir-NS was 5.49, 3.90, and 0.72, respectively. The K/Mn atomic ratio of Bir-NF, Bir-NW, and Bir-NS, measured by ICP-OES analysis, was $0.10,0.25$, and 0.33 , respectively [23]. $\mathrm{N}_{2}$ adsorption/desorption revealed that BET specific surface areas of Bir-NS, Bir-NW, and Bir-NF were 19.0, 98.0, and $162.6 \mathrm{~m}^{2} \mathrm{~g}^{-1}$, respectively [23].

\subsection{As(III) oxidation performance}

Bir-NS showed the lowest As(III) oxidation activity (Fig 1A). After $30 \mathrm{~min}, 7.8 \%$ of As(III) species were oxidized to As(V). In comparison, Bir-NW removed up to $40.3 \%$ As(III) after 30 min whilst Bir-NF removed $98.7 \%$ As(III) after 30 min, generating the greatest As(III) oxidation activity. Arsenic oxidation state on Bir-NF surfaces was analyzed by fitting As3d XPS spectra. As shown in Fig S5, only one peak at $45.3 \mathrm{eV}$, was assigned to As(V) species [15,28]. This was decomposed from As3d XPS spectra, indicating that As(III) species in the initial As solution were oxidized to As(V) before being adsorbed onto birnessite surfaces. FTIR spectra of Bir-NF before and after reaction with As(III) are presented in Fig. S6. For fresh Bir-NF samples, peaks at $\sim 530, \sim 480$, and $\sim 420 \mathrm{~cm}^{-1}$ were assigned to Mn-O stretching vibrations in birnessite $[29,30]$. After reaction with $\mathrm{As}(\mathrm{III})$, a new peak at $\sim 820 \mathrm{~cm}^{-1}$, attributed to $\mathrm{As}(\mathrm{V})-\mathrm{O}$ stretching vibration [15,31], was observed. It is noteworthy that the As(III)-O vibration, has a characteristic peak at $\sim 580 \mathrm{~cm}^{-1}[31]$, 
form, which is consistent with XPS analysis.

The development of As(III) and As(V) concentrations in aqueous and solid phases was examined during reaction with the initial As(III) concentration and Bir-NF sample at $\mathrm{pH}$ 6.0. In the aqueous phase, after $30 \mathrm{~min}$, arsenite and arsenate concentrations reached 1.3 and $79 \mu \mathrm{mol} \mathrm{L} \mathrm{L}^{-1}$ respectively (Fig. S7). In the solid phase, the calculated arsenic concentration was $19.7 \mu \mathrm{mol} \mathrm{L}^{-1}$ (Fig. S7) which indicates that most of the arsenic species were dissolved in the aqueous phase, which is in agreement with previous reports [1,32]. FTIR and As3d XPS spectra analyses revealed that unreacted As(III) species only existed in the aqueous phase, rather than the solid phase. Therefore, the residual As(III) concentration in the aqueous phase may be used to evaluate $\mathrm{As}(\mathrm{III})$ to $\mathrm{As}(\mathrm{V})$ transformations by birnessite.

Arsenite oxidation on birnessite follows first-order kinetics [14] with an initial reaction time of $30 \mathrm{~min}$ (Fig S8). Arsenite oxidation rate constant $\left(k_{\mathrm{c}}\right)$ of Bir-NS was very low, $2.2 \times 10^{-3} \mathrm{~min}^{-1}$, whereas for Bir-NW, it increased to $1.4 \times 10^{-2} \mathrm{~min}^{-1}$. The highest rate constant, Bir-NF, at $0.137 \mathrm{~min}^{-1}$, was 9.3 and 62.3 times greater than Bir-NW and Bir$\mathrm{NS}$, respectively. We also compared the initial production rate of arsenate, $r_{\mathrm{As}(\mathrm{V})}$ (the concentration of $\mathrm{As}(\mathrm{V})$ produced per gram of oxidant per unit time) on different birnessites to further evaluate As(III) oxidation performance. Bir-NF showed the greatest $r_{\mathrm{As}(\mathrm{V})}\left(14.0 \mu \mathrm{mol} \mathrm{g}^{-1} \mathrm{~min}^{-1}\right)$ followed by Bir-NW $\left(6.4 \mu \mathrm{mol} \mathrm{g} \mathrm{g}^{-1} \mathrm{~min}^{-1}\right)$ then Bir-NS $\left(0.2 \mu \mathrm{mol} \mathrm{g}^{-1}\right.$ $\min ^{-1}$ ) (Fig. 1B), indicating that birnessite morphology had a significant effect on As(III) removal.

It is widely accepted that oxidation of As(III) by manganese oxide couples with adsorption of $\mathrm{As}(\mathrm{V})$ produced. In addition, both $\mathrm{As}(\mathrm{III})$ and $\mathrm{As}(\mathrm{V})$ species coexist in polluted groundwater [33, 34]. Arsenate has a greater affinity for manganese oxide than As(III), and so occupation of activity sites on manganese oxide surfaces by $\mathrm{As}(\mathrm{V})$ may result in reduction of As(III) oxidation. In order to demonstrate whether As(V) affects As(III) removal on birnessite, $0.1 \mathrm{mmol} \mathrm{L}^{-}$ ${ }^{1}$ As(V) was added to the initial As(III) solutions. It was revealed that As(III) removal on Bir-NW and Bir-NS was considerably reduced from $24.8 \%$ and $3.6 \%$ (Fig. 2). Nevertheless, following addition of $0.1 \mathrm{mmol} \mathrm{L}^{-1} \mathrm{As}(\mathrm{V})$, As(III) removal with Bir-NF reached $98.0 \%$. These results demonstrate that the strategy for controlling birnessite morphology not only promotes the rate of As(III) oxidation kinetics, but can also prevents As(V) coexisting with As(III) oxidation in this case.

Arsenite oxidation is controlled by kinetics, and competitive adsorption of coexisting ions, which passivates the 
surface active sites and blocks As(III) oxidation. To determine if the effect of $\mathrm{As}(\mathrm{V})$ on $\mathrm{As}(\mathrm{III})$ oxidation originated from different $\mathrm{As}(\mathrm{V})$ adsorption rates, $\mathrm{As}(\mathrm{V})$ adsorption capacity was compared. All samples adsorbed $\mathrm{As}(\mathrm{V})$ revealing adsorption capacities for Bir-NF, Bir-NW, and Bir-NS as 32.7, 13.5, and $8.7 \mu \mathrm{mol} \mathrm{g}{ }^{-1}$, respectively (Fig. 2B). The decrease in As(III) oxidation activity for Bir-NW and Bir-NS, after addition of As(V), may be attributed to competitive adsorption by $\mathrm{As}(\mathrm{V})$; arsenate occupies the active sites and interferes with contact between $\mathrm{As}(\mathrm{III})$ and birnessite. Nevertheless, Bir-NF, demonstrated the greatest As(V) adsorption capacity. Specific adsorption capacity, defined as the concentration of $\mathrm{As}(\mathrm{V})$ adsorbed per unit surface area per gram of sample was also assessed. Bir-NF also possesses the greatest specific adsorption capacity (Fig. 2B, blue column). This shows that competitive adsorption of As(V) had no effect on As(III) oxidation activity with Bir-NF. Rapid As(III) oxidation kinetics consequently plays a critical role in As (III) removal, which counteracts the adverse effects of As(V) adsorption.

Phosphate has the same molecular structure as arsenate, and was chosen as a competitive ion to explain the adsorption effect of As(III) oxidation activity on birnessite. After addition of $0.1 \mathrm{mmol} \mathrm{L}^{-1}$ phosphate, As(III) removal on Bir-NS and Bir-NW was $2.1 \%$ and $20.1 \%$, respectively, being reduced by $5.7 \%$ and $20.2 \%$ compared to no phosphate (Fig. 3A, green column). This has been observed in previous work, and is attributed to the favorable occupation of phosphate species on surface active sites, resulting in the decreasing interaction of As(III) on birnessite surfaces [12,35]. However, phosphate had no significant effect on Bir-NF, with 97.0\% As(III) removed from solution (Fig. 3A). Birnessite phosphate adsorption kinetics at $0.1 \mathrm{mmol} \mathrm{L}^{-1}$ were fitted using pseudo-first-order and pseudo-second-order models (Fig. 3B). The model equations are as follows:

$$
\begin{gathered}
\text { pseudo-first-order model: } q_{t}=q_{e}\left(1-e^{-k 1 \mathrm{t}}\right) \\
\text { pseudo-second-order model: } \mathrm{t} / q_{t}=\mathrm{t} / q_{\mathrm{e}}+1 /\left(k_{2} \mathrm{qe}_{\mathrm{e}}{ }^{2}\right)
\end{gathered}
$$

where $\mathrm{t}$ is the adsorption time (min); $q_{\mathrm{e}}$ and $q_{\mathrm{t}}$ represent the phosphate adsorption concentration at equilibrium and at

time $\mathrm{t},(\mu \mathrm{mol} / \mathrm{g}) ; k_{1}\left(\mathrm{~min}^{-1}\right)$ and $k_{2}\left(\mathrm{~g} \mu \mathrm{mol}^{-1} \mathrm{~min}^{-1}\right)$ are the rate constants of the pseudo-first-order and pseudo-secondorder.

As shown in Fig 3B, the adsorption of phosphate on three birnessite samples can achieve adsorption equilibrium after $100 \mathrm{~min}$. For Bir-NW and Bir-NS samples, their phosphate adsorption kinetics rates $\left(k_{1}\right)$ are 0.137 and $0.080 \mathrm{~min}^{-1}$, 
respectively (Table S1), which are far higher than their As(III) oxidation kinetics rates (corresponding to $1.4 \times 10^{-2}$ and $2.2 \times 10^{-3} \mathrm{~min}^{-1}$, respectively). This reveals that phosphate adsorption on Bir-NW and Bir-NS is faster than As(III) oxidation, consequently resulting in a decrease in As(III) removal due to the fast occupation of phosphate on birnessite surface active sites. The phosphate adsorption kinetics rate $\left(0.130 \mathrm{~min}^{-1}\right)$ of Bir-NW is lower than its As(III) oxidation kinetics rate $\left(0.137 \mathrm{~min}^{-1}\right)$, suggesting that oxidation of $\mathrm{As}(\mathrm{III})$ on Bir-NF is faster than adsorption of phosphate. Elevated As(III) oxidation activity on birnessite following phosphate addition may be attributed to its rapid As(III) oxidation kinetics.

The effect of $\mathrm{Mn}^{2+}$ on As(III) removal was also assessed, as soluble $\mathrm{Mn}^{2+}$ released from manganese oxide can be readsorbed. Addition of $0.1 \mathrm{mmol} \mathrm{L}^{-1} \mathrm{Mn}^{2+}$ reduced As(III) removal by $32.5 \%$ and $3.2 \%$ on Bir-NW and Bir-NS respectively. No change was observed with Bir-NF (98.1\%) (Fig. 3A (blue column)), again demonstrating that by modifying birnessite morphology, oxidation of $\mathrm{As}(\mathrm{III})$ to $\mathrm{As}(\mathrm{V})$ can be achieved, negating the adverse effect of coexisting ions such as $\mathrm{Mn}^{2+}$.

Typical phosphate concentrations in industrial wastewater or groundwater vary from 0 to $125 \mathrm{mg} \mathrm{PO}_{4}-\mathrm{P} \mathrm{L}^{-1}$ [36-39]. The effect of phosphate and Bir-NF was therefore investigated by adding $0.1,1.0$, and $4 \mathrm{mmol} \mathrm{L}^{-1}$ phosphate corresponding to $3.1,31$, and $124 \mathrm{mg} \mathrm{L}^{-1}$, into As(III) solutions at $\mathrm{pH} 6.0$ (Fig. 4A). Phosphate, (1.0 mmol L-1), removed $78.0 \% \mathrm{As}(\mathrm{III})$, much less than at $0.1 \mathrm{mmol} \mathrm{L}^{-1}$. Increasing the concentration from 1.0 to $4.0 \mathrm{mmol} \mathrm{L}^{-1}$, showed a decrease in arsenite from $78.0 \%$ to $65.5 \%$. This revealed that the presence of higher concentrations of phosphate in wastewater is unfavorable to As(III) removal on birnessite. We also investigated phosphate adsorption kinetics on Bir$\mathrm{NF}$ at $4 \mathrm{mmol} \mathrm{L}^{-1}$ (Fig. 4B). Phosphate adsorption kinetics rate increased slightly from 0.130 to $0.138 \mathrm{~min}^{-1}$ (Table S2). This is close to As(III) oxidation kinetics $\left(0.137 \mathrm{~min}^{-1}\right)$, suggesting that As(III) oxidation behavior is consistent with phosphate adsorption behavior. For this reason, competitive adsorption of phosphate at high concentration can't be disregarded. We also evaluated $\mathrm{Mn}^{2+}$ ion concentrations ranging from 0.1 to $10 \mathrm{mmol} \mathrm{L}^{-1}$ and revealing that arsenite removal considerably decreased with increasing $\mathrm{Mn}^{2+}$ concentration (Fig. S9). This showed that $\mathrm{Mn}^{2+}$ at high concentrations had a greater effect than that of phosphate.

Original As(III) concentration on As(III) removal on Bir-NF was also evaluated by diluting the As(III) stock solution 
to a concentration range between 0.05 and $0.5 \mathrm{mmol} \mathrm{L}^{-1}$ at $\mathrm{pH}$ 6.0. At $0.05 \mathrm{mmol} \mathrm{L}^{-1}$, As(III) rapidly oxidized to As(V) in $5 \mathrm{~min}$ from an initial concentration of $0.05 \mathrm{mmol} \mathrm{L}^{-1}$ (Fig. 5A). Increasing As(III) concentration from 0.05 to $0.1,0.2$, 0.3 , and $0.5 \mathrm{mmol} \mathrm{L}^{-1}$, showed a considerable decrease from $87.6 \%$ to $73.7 \%, 45.0 \%, 29.3 \%$, and $12.0 \%$, respectively.

The effect of Bir-NF quantity on As(III) removal was investigated using 0.2 to $1.0 \mathrm{~g} \mathrm{~L}^{-1}$ at $\mathrm{pH}$ 6.0. Arsenite removal at $0.2 \mathrm{~g} \mathrm{~L}^{-1}$ Bir-NF was $21.0 \%$ within $5 \mathrm{~min}$. Upon increasing Bir-NF to 0.4, 0.6, 0.8, and $1.0 \mathrm{~g} \mathrm{~L}^{-1}$, As(III) removal increased to $58.0 \%, 73.5 \%, 83.7 \%$, and 99.1\%, within 5min, respectively (Fig. 5B). In addition, after $30 \mathrm{~min}$, As(III) removal at $0.6 \mathrm{~g} \mathrm{~L}^{-1}$ Bir-NF was very close to those of $0.8 \mathrm{~g} \mathrm{~L}^{-1}$ and $1.0 \mathrm{~g} \mathrm{~L}^{-1}$, indicating that oxidation rate (as defined as the amount of As(III) oxidized per gram per minute) at high concentration is lower than that at low concentration, which was also observed in previous work [1,17].

The effect of $\mathrm{pH}$ on As(III) removal with Bir-NF was investigated at 4.7, 6.0, and 9.16 (Fig. S11). Arsenite removal on Bir-NF at pH 6.0 was very close to that at $\mathrm{pH} 4.7$ (95.4\%) and 9.16 (97.5\%), suggesting Bir-NF has a strong pH adaptability, which is critical for application of Bir-NF in As(III) removal.

\subsection{Origin of morphology effect on As(III) oxidation}

\subsubsection{Surface area, $\mathrm{Mn}$ Average Oxidation State, and $\mathrm{Mn}^{2+}$ release.}

Specific surface area. Oxidation rates of As(III) are presented in Table 1. Bir-NF has the greatest As(III) oxidation rate $\left(24.7 \mu \mathrm{mol} \mathrm{g}^{-1} \mathrm{~min}^{-1}\right)$, followed by Bir-NW $\left(9.3 \mu \mathrm{mol} \mathrm{g}^{-1} \min ^{-1}\right)$ and Bir-NS $\left(1.4 \mu \mathrm{mol} \mathrm{g}^{-1} \mathrm{~min}^{-1}\right)$. All birnessite samples showed different BET surface areas and specific As(III) oxidation rates (the amount of As(III) reacted per unit $S_{\text {BET }}$ per unit time). Bir-NF revealed the greatest specific As(III) oxidation rate at $0.15 \mu \mathrm{mol} \mathrm{m}^{-2} \mathrm{~min}^{-1}$, being 1.6 and 1.8 times higher than Bir-NW and Bir-NS.

Mn Average Oxidaiton State (Mn AOS): Mn AOS of birnessites with different morphologies was qualitatively calculated by fitting Mn3s peaks. The formula for calculating the Mn AOS is described elsewhere [23, 40]. The calculated Mn AOS for Bir-NF, Bir-NW, and Bir-NS are 3.13, 3.23, and 3.48, respectively. The presence of low Mn AOS in Bir-NF may be due to its lower preparation temperature $\left(50^{\circ} \mathrm{C}\right)$, which is unfavorable to the crystallinity of birnessite, thus resulting in defects (e.g., oxygen vacancy). This observation was confirmed by calculating their relative oxygen vacancy defect (OVD) concentration by combining both $\mathrm{K} / \mathrm{Mn}$ atomic ratio and $\mathrm{Mn}^{3+} / \mathrm{Mn}^{4+}$ atomic ratio, which 
is based on all birnessite samples that have the same crystalline structure. Bir-NF has the highest OVD concentration (0.39), followed by Bir-NW (0.26) and Bir-NS (0.08). This illustrates the significant difference between As(III) oxidation rates and birnessite morphologies and may be related to the oxygen vacancy defect; the higher the OVD concentration, the greater the As(III) oxidation activity.

Detection of dissolved $\mathrm{Mn}^{2+}$ : It is well known that oxidation of As(III) by birnessite follows a typical electron transfer mechanism $[13,14,16,41]$, i.e., As(III) species firstly adsorb onto manganese oxide surfaces in bidentatebinuclear form [14,16,42] (Fig. 8). Two electrons from As(III) transfer to each of the bonded Mn atoms, producing $\mathrm{H}_{3} \mathrm{AsO}_{4}$ and two surface $\mathrm{Mn}(\mathrm{III})$ ions [13]:

$$
2 \mathrm{MnO}_{2}+\mathrm{H}_{3} \mathrm{AsO}_{3} \longrightarrow 2 \mathrm{Mn}^{\mathrm{III}} \mathrm{OOH}^{*}+\mathrm{H}_{3} \mathrm{AsO}_{4}
$$

where $\mathrm{MnOOH}^{*}$ is a $\mathrm{Mn}(\mathrm{III})$ intermediate reaction product. Another As(III) species subsequently adsorbs to two Mn(III) ions forming a bidentate surface complex, and two electrons from As(III) transfer to each of the bonded Mn(III) ions, hence leading to the production of $\mathrm{As}(\mathrm{V})$ and the release of $\mathrm{Mn}^{2+}$ ions from manganese oxide surfaces[13]:

$$
\mathrm{MnOOH}^{*}+\mathrm{H}_{3} \mathrm{AsO}_{3}+4 \mathrm{H}^{+} \longrightarrow 2 \mathrm{Mn}^{2+}+\mathrm{H}_{3} \mathrm{AsO}_{4}+3 \mathrm{H}_{2} \mathrm{O}
$$

The overall reaction can be described as follows:

$$
\mathrm{MnO}_{2}+\mathrm{H}_{3} \mathrm{AsO}_{3}+2 \mathrm{H}^{+} \longrightarrow \mathrm{Mn}^{2+}+\mathrm{H}_{3} \mathrm{AsO}_{4}+\mathrm{H}_{2} \mathrm{O}
$$

Based on the above mechanism, the faster the electron transfer of arsenite to $\mathrm{Mn}$, the greater the $\mathrm{Mn}^{2+}$ concentration released, and the faster the $\mathrm{As}(\mathrm{III})$ oxidation rate on birnessite. Thus, the evolution of $\mathrm{Mn}^{2+}$ produced from different birnessite samples was employed to evaluate As(III) electron transfer rate. The evolution of $\mathrm{Mn}^{2+}$ produced with the reaction time on different samples is shown in Fig. 6. For Bir-NS, after $30 \mathrm{~min}, \mathrm{Mn}^{2+}$ released in solution was 0.010 mmol L ${ }^{-1}$. For Bir-NF, $\mathrm{Mn}^{2+}$ increased to $0.052 \mathrm{mmol} \mathrm{L}^{-1}$. The greatest $\mathrm{Mn}^{2+}$ concentration was observed with Bir-NF at $0.081 \mathrm{mmol} \mathrm{L}^{-1}$. A blank test for $\mathrm{Mn}^{2+}$ release from Bir-NF, Bir-NW, and Bir-NS samples in the absence of As(III) at $\mathrm{pH}$ 6.0 was also determined (Fig. 6, cyan, magenta, and dark yellow lines represent blank tests using Bir-NF, Bir-NW, and Bir-NS, respectively). The blank tests show that $\mathrm{Mn}^{2+}$ concentration in solution was not detected during the entire reaction time of $30 \mathrm{~min}$, indicating that $\mathrm{Mn}^{2+}$ release from the three birnessite samples did not occur in the absence of $\mathrm{As}(\mathrm{III})$ in this case. $\mathrm{Mn}^{2+}$ production rate $\left(r_{\mathrm{Mn} 2+}\right)$ was also compared with Bir-NF producing $27.0 \mu \mathrm{mol} \mathrm{g}^{-1} \mathrm{~min}^{-1}$, being 
1.5 and 8.1 times faster than Bir-NW and Bir-NS. This reveals that the higher dissolved $\mathrm{Mn}^{2+}$ concentration in Bir-NF is attributed to the faster electron transfer from As atoms to Mn atoms, thus considerably improving its As(III) oxidation rate.

\subsubsection{Surface charge characteristics}

Due to diverse morphologies having different oxygen vacancy defect concentrations, the effect of OVD on surface charge characteristics was investigated by measuring their point of zero charge $\left(\mathrm{pH}_{P Z C}\right)$, which can be used to explain adsorption properties (Fig. 7). For Bir-NS with the lowest OVD concentration, its $\mathrm{pH}_{P Z C}$ was lower than 0.36, creating negatively charged sites at $\mathrm{pH} 6.0$, and so making it difficult for As to adsorb. Increasing the OVD concentration increased the $\mathrm{pH}_{P Z C}$ to 0.67 , but Bir-NS with the highest OVD concentrations showed the $\mathrm{pH}_{P Z C}$ to increase to 1.73 . This demonstrates that increasing oxygen vacancy defect concentration in birnessite facilitates $\mathrm{pH}_{P Z C}$ shift to high $\mathrm{pH}$, thus decreasing electrostatic repulsion and promoting As species adsorption on birnessite at near neutral $\mathrm{pH}$ values.

\subsubsection{DFT calculation}

To reveal the effect of oxygen vacancy defect on As(III) oxidation, As(V) and As(III) adsorption energies were calculated in the presence or absence of one OVD using density functional theory (DFT) calculations. The $\{100\}$ slab birnessite surface was constructed according to XRD analysis and HRTEM images. The OVD site in $\{100\}$ slab surface is shown in Fig. S12. In solution, the $\mathrm{H}_{2} \mathrm{O}$ molecule can adsorb onto the $\{100\}$ plane surface and rapidly occupy the OVD site. To perform the calculation $\mathrm{HAsO}_{4}{ }^{2-}$ was used. $\mathrm{HAsO}_{4}{ }^{2-}$ adsorbed on the $\{100\}$ plane surfaces by the bidentate-binuclear model. The formula for calculating the adsorption energy is as follows:

$$
E_{a d s}=E_{\text {total }}-E_{\text {slab }}-E_{\text {HAsO } 42-}
$$

where $E_{\text {total }}$ is the total energy of the $\{100\}$ surface with a $\mathrm{H}_{2} \mathrm{O}$ molecule after $\mathrm{HAsO}_{4}{ }^{2-}$ adsorption, $E_{\text {slab }}$ is the energy

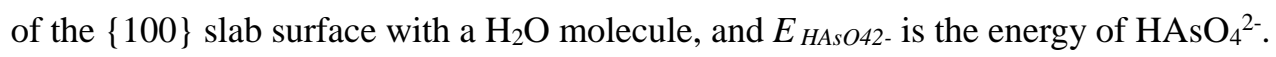

The calculated adsorption energy of $\mathrm{HAsO}_{4}{ }^{2-}$ on the $\{100\}$ slab surface is $-1.55 \mathrm{eV}$, suggesting $\mathrm{HAsO}_{4}{ }^{2-}$ adsorbed on the birnessite surface is thermodynamically favorable. For the $\{100\}$ slab surface in the presence of one OVD, the $E_{a d s}$ of $\mathrm{HAsO}_{4}{ }^{2-}$ decreased to $-5.27 \mathrm{eV}$ revealing that the adsorption of $\mathrm{HAsO}_{4}{ }^{2-}$ was easier in the presence of one OVD at the $\{100\}$ slab surface, which is consistent with experimental results for $\mathrm{As}(\mathrm{V})$ adsorption. 
Adsorption energy was also calculated for $\mathrm{HAsO}_{3}{ }^{2-}$ on the $\{100\}$ slab surface in the presence and absence of one

OVD. The adsorption model for $\mathrm{HAsO}_{3}{ }^{2-}$ on the $\{100\}$ slab surface is similar to Fig. $\mathrm{S} 13$ but $\mathrm{HAsO}_{3}{ }^{2-}$ replaces $\mathrm{HAsO}_{4}{ }^{2-}$

(Fig. 8). In the absence of OVD, the $E_{a d s}$ of $\mathrm{HAsO}_{3}{ }^{2-}$ near the site of the $\mathrm{H}_{2} \mathrm{O}$ molecule was $-1.58 \mathrm{eV}$. The $E_{a d s}$ of $\mathrm{HAsO}_{3}{ }^{2-}$ decreased to $-3.40 \mathrm{eV}$ in the presence of one OVD on the $\{100\}$ slab surface, suggesting that the presence of OVD on the $\{100\}$ slab surface facilitates the adsorption of As(III) species on birnessite surfaces. Enhanced adsorption performance of As(III) species on birnessite is important for improving rapid As(III) oxidation.

The application of adsorption techniques has been widely investigated for As removal, and iron oxides are highly efficient adsorbents that have invited much interest. Due to As(III) having a weaker affinity for iron oxides compared to $\mathrm{As}(\mathrm{V})$, the oxidation of $\mathrm{As}(\mathrm{III})$ to $\mathrm{As}(\mathrm{V})$ by manganese oxides is an essential step for facilitating adsorption of As species on iron oxides in As contaminated wastewater. Arsenite removal on iron oxide can be significantly enhanced in the presence of manganese oxide. This is due to the oxidation of As(III) by manganese oxide, and then adsorption of $\mathrm{As}(\mathrm{V})$ produced by iron oxides. Arsenite is rapidly oxidized to $\mathrm{As}(\mathrm{V})$ by manganese oxides, and subsequently adsorbed by iron oxides, which is a practical approach to reduce the toxicity of As in wastewaters. This will be investigated further in future work.

\section{Conclusions}

In summary, birnessite-type manganese oxides with morphologies of nanoflower, nanowire, and nanosheet were selected to oxidize $\operatorname{As}(\mathrm{III})$ species from arsenic-containing wastewater. Experimental results have revealed that nanoflower-like birnessite exhibits remarkably higher oxidation activity for As(III) removal in comparison to nanowirelike and nanosheet-like birnessites. By varying the morphology of birnessite from nanosheet to nanoflower, it not only promotes As(III) oxidation, but also reduces the adverse effect of adsorption of coexisting ions on As(III) removal. The enhancement of As(III) oxidation activity in nanoflower-like birnessite is attributed to its high oxygen vacancy defect concentration, which not only facilitates the highly efficient contact between As(III) species and manganese oxide, but also accelerates charge transfer from As atoms to Mn atoms, thus significantly promoting As(III) oxidation activity. The present work provides a novel insight towards improving As(III) oxidation performance by controlling birnessite-type manganese oxide morphology. 
This work was supported by the Fundamental Research Funds for the Central Universities (No. 2662017QD013), China Postdoctoral Science Foundation (2015M580674), and Opening Foundation of the Chinese National Engineering Research Center for Control and Treatment of Heavy metal Pollution, Changsha, 410083, China (No. 2015CNERCCTHMP-03).

\section{Appendix A. Supplementary data}

Change in $\mathrm{pH}$ values at different buffer solutions, FSEM and HRTEM images, XRD patterns, XPS full spectra of birnessites with different morphologies, As 3d XPS and FTIR spectra of the Bir-NF sample before and after reaction with $0.1 \mathrm{mM}$ As (III) solution, Change of arsenic species concentration with reaction time in aqueous phase and solid phase, the fitting result of $\mathrm{As}(\mathrm{III})$ oxidation on birnessites, the effect of $\mathrm{Mn}^{2+}$ concentration and $\mathrm{pH}$ value on As(III) removal, and the calculated model of $\mathrm{HAsO}_{4}{ }^{2-}$ adsorbed on $\{100\}$ surface are available in the online version.

\section{References}

[1] X.J. Li, C.S. Liu, F.B. Li, Y.T. Li, L.J. Zhang, C.P. Liu, Y.Z. Zhou, The oxidative transformation of sodium arsenite at the interface of ??-MnO2 and water, J. Hazard. Mater. 173 (2010) 675-681. doi:10.1016/j.jhazmat.2009.08.139.

[2] D. Kim, A.D. Bokare, M. suk Koo, W. Choi, Heterogeneous catalytic oxidation of As(III) on nonferrous metal oxides in the presence of H2O2., Environ. Sci. Technol. 49 (2015) 3506-3513. doi:10.1021/es5056897.

[3] M.J. Kim, J. Nriagu, Oxidation of arsenite in groundwater using ozone and oxygen, Sci. Total Environ. 247 (2000) 71-79. doi:10.1016/S0048-9697(99)00470-2.

[4] S. Sorlini, F. Gialdini, Conventional oxidation treatments for the removal of arsenic with chlorine dioxide, hypochlorite, potassium permanganate and monochloramine, Water Res. 44 (2010) 5653-5659. doi:10.1016/j.watres.2010.06.032.

[5] S. Sorlini, F. Gialdini, M. Stefan, Arsenic oxidation by UV radiation combined with hydrogen peroxide., Water Sci. Technol. 61 (2010) 339-344. doi:10.2166/wst.2010.799.

[6] M. Pettine, L. Campanella, F.J. Millero, Arsenite oxidation by $\mathrm{H} 2 \mathrm{O} 2$ in aqueous solutions, Geochim. Cosmochim. Acta. 63 (1999) 2727-2735. doi:10.1016/S0016-7037(99)00212-4. 
[7] V.K. Sharma, M. Sohn, Aquatic arsenic: toxicity, speciation, transformations, and remediation., Environ. Int. 35 (2009) 743-59. doi:10.1016/j.envint.2009.01.005.

[8] K.S. Ng, Z. Ujang, P. Le-Clech, Arsenic removal technologies for drinking water treatment, Rev. Environ. Sci. Bio/Technology. 3 (2004) 43-53. doi:10.1023/B:RESB.0000040054.28151.84.

[9] S.L. Suib, Sieves and Octahedral Layered Materials, Acc. Chem. Res. 41 (2008) 479-487.

[10] J.N. Moore, J.R. Walker, T.H. Hayes, Reaction scheme for the oxidation of As (III) to As (V) by birnessite, 38 (1990) $549-555$.

[11] C. Tournassat, L. Charlet, D. Bosbach, A. Manceau, Arsenic(III) oxidation by birnessite and precipitation of manganese(II) arsenate, Environ. Sci. Technol. 36 (2002) 493-500. doi:10.1021/es0109500.

[12] S.J. Parikh, B.J. Lafferty, T.G. Meade, D.L. Sparks, Evaluating environmental influences on asIII oxidation kinetics by a poorly crystalline Mn-oxide, Environ. Sci. Technol. 44 (2010) 3772-3778. doi:10.1021/es903408g.

[13] H.W. Nesbitt, G.W. Canning, G.M. Bancroft, XPS study of reductive dissolution of $7 \AA ̊$-birnessite by H3AsO3, with constraints on reaction mechanism, Geochim. Cosmochim. Acta. 62 (1998) 2097-2110. doi:10.1016/S00167037(98)00146-X.

[14] B. a. Manning, S.E. Fendorf, B. Bostick, D.L. Suarez, Arsenic(III) oxidation and arsenic(V) adsorption reactions on synthetic birnessite, Environ. Sci. Technol. 36 (2002) 976-981. doi:10.1021/es0110170.

[15] J. Hou, J. Luo, S. Song, Y. Li, Q. Li, The remarkable effect of the coexisting arsenite and arsenate species ratios on arsenic removal by manganese oxide, Chem. Eng. J. 315 (2017) 159-166. doi:10.1016/j.cej.2016.12.115.

[16] M. Zhu, K.W. Paul, J.D. Kubicki, D.L. Sparks, Quantum chemical study of arsenic (III, V) adsorption on Mn-oxides: Implications for arsenic(III) oxidation, Environ. Sci. Technol. 43 (2009) 6655-6661. doi:10.1021/es900537e.

[17] J. Hou, J. Luo, Z. Hu, Y. Li, M. Mao, S. Song, Q. Liao, Q. Li, Tremendous effect of oxygen vacancy defects on the oxidation of arsenite to arsenate on cryptomelane-type manganese oxide, Chem. Eng. J. 306 (2016) 506-606. doi:10.1016/j.cej.2016.07.072.

[18] S.J. Parikh, B.J. Lafferty, T.G. Meade, D.L. Sparks, Evaluating environmental influences on asIII oxidation kinetics by a poorly crystalline Mn-oxide, Environ. Sci. Technol. 44 (2010) 3772-3778. doi:10.1021/es903408g. 
[19] H. Yin, F. Liu, X. Feng, M. Liu, W. Tan, G. Qiu, Co2+-exchange mechanism of birnessite and its application for the removal of Pb2+ and As(III), J. Hazard. Mater. 196 (2011) 318-326. doi:10.1016/j.jhazmat.2011.09.027.

[20] M. Villalobos, I.N. Escobar-Quiroz, C. Salazar-Camacho, The influence of particle size and structure on the sorption and oxidation behavior of birnessite: I. Adsorption of As(V) and oxidation of As(III), Geochim. Cosmochim. Acta. 125 (2014) 564-581. doi:10.1016/j.gca.2013.10.029.

[21] H.T. Zhu, J. Luo, H.X. Yang, J.K. Liang, G.H. Rao, J.B. Li, Z.M. Du, Birnessite-type MnO 2 Nanowalls and Their Magnetic Properties, (2008) 17089-17094.

[22] L.J. and W.Z. Xiaochuan Duan, Jiaqin Yang, Haiyan Gao, Jianmin Ma, CrystEngComm Controllable hydrothermal synthesis of manganese dioxide nanostructures : shape evolution, growth mechanism and electrochemical properties $\{$, (2012) 4196-4204. doi:10.1039/c2ce06587h.

[23] J. Hou, Y. Li, M. Mao, L. Ren, X. Zhao, Tremendous effect of the morphology of birnessite-type manganese oxide nanostructures on catalytic activity., ACS Appl. Mater. Interfaces. 6 (2014) 14981-7. doi:10.1021/am5027743.

[24] S. Liang, F. Teng, G. Bulgan, R. Zong, Y. Zhu, Effect of Phase Structure of MnO 2 Nanorod Catalyst on the Activity for CO Oxidation, (2008) 5307-5315.

[25] D.W. Oscarson, P.M. Huang, W.K. Liaw, The Oxidation of Arsenite by Aquatic Sediments1, J. Environ. Qual. 9 (1980) 700.

[26] W. Tan, S. Lu, F. Liu, X. Feng, J. He, L.K. Koopal, Determination of the Point-of-Zero Charge of Manganese Oxides With Different Methods Including an Improved Salt Titration Method, Soil Sci. 173 (2008) 277-286. doi:10.1097/SS.0b013e31816d1f12.

[27] L.J. and W.Z. Xiaochuan Duan, Jiaqin Yang, Haiyan Gao, Jianmin Ma, CrystEngComm Controllable hydrothermal synthesis of manganese dioxide nanostructures : shape evolution, growth mechanism and electrochemical properties $\{$, (2012) 4196-4204. doi:10.1039/c2ce06587h.

[28] S. Ouvrard, P. de Donato, M.O. Simonnot, S. Begin, J. Ghanbaja, M. Alnot, Y.B. Duval, F. Lhote, O. Barres, M. Sardin, Natural manganese oxide: Combined analytical approach for solid characterization and arsenic retention, 
[29] D.S. Yang, M.K. Wang, Syntheses and Characterization of Well-Crystallized Birnessite, (2001) $2589-2594$.

[30] X. Yang, Y. Makita, Z. Liu, K. Sakane, K. Ooi, Structural Characterization of Self-Assembled MnO 2 Nanosheets from Birnessite Manganese Oxide Single Crystals, (2004) 5581-5588.

[31] G.S. Zhang, J.H. Qu, H.J. Liu, R.P. Liu, G.T. Li, Removal mechanism of As(III) by a novel Fe-Mn binary oxide adsorbent: Oxidation and sorption, Environ. Sci. Technol. 41 (2007) 4613-4619. doi:10.1021/es063010u.

[32] H. Yin, X. Feng, G. Qiu, W. Tan, F. Liu, Characterization of Co-doped birnessites and application for removal of lead and arsenite., J. Hazard. Mater. 188 (2011) 341-9. doi:10.1016/j.jhazmat.2011.01.129.

[33] P.L. Smedley, D.G. Kinniburgh, A review of the source, behaviour and distribution of arsenic in natural waters, 17 (2002) 517-568.

[34] H.J. Reisinger, D.R. Burris, J.G. Hering, Remediating subsurface arsenic contamination with monitored natural attenuation., Environ. Sci. Technol. 39 (2005) 458A-464A. doi:10.1021/es053388c.

[35] V. Chiu, J. Hering, Arsenic adsorption and oxidation at manganite surfaces. 1. Method for simultaneous determination of adsorbed and dissolved arsenic species, Environ. Sci. Technol. 34 (2000) 2029-2034. doi:10.1021/es990788p.

[36] A. Broughton, S. Pratt, A. Shilton, Enhanced biological phosphorus removal for high-strength wastewater with a low rbCOD : P ratio, 99 (2008) 1236-1241. doi:10.1016/j.biortech.2007.02.013.

[37] J. Qian, L. Wang, H. Zhan, Urban land-use effects on groundwater phosphate distribution in a shallow aquifer, Nanfei River basin , China, (2011) 1431-1442. doi:10.1007/s10040-011-0770-x.

[38] M. Pijuan, A. Oehmen, J.A. Baeza, C. Casas, Z. Yuan, Characterizing the Biochemical Activity of Full-Scale Enhanced Biological Phosphorus Removal Systems : A Comparison With Metabolic Models, 99 (2008) $170-179$. doi:10.1002/bit.

[39] S.R. Chowdhury, E.K. Yanful, Arsenic and chromium removal by mixed magnetite e maghemite nanoparticles and the effect of phosphate on removal, J. Environ. Manage. 91 (2010) 2238-2247. doi:10.1016/j.jenvman.2010.06.003.

[40] V.P. Santos, O.S.G.P. Soares, J.J.W. Bakker, M.F.R. Pereira, J.J.M. Órfão, J. Gascon, F. Kapteijn, J.L. Figueiredo, Structural and chemical disorder of cryptomelane promoted by alkali doping: Influence on catalytic properties, J.

Catal. 293 (2012) 165-174. doi:10.1016/j.jcat.2012.06.020. 
[41] J.N. Moore, J.R. Walker, T.H. Hayes, Reaction scheme for the oxidation of As(III) to As(V) by Birnessite, Clays Clay Miner. 38 (1990) 549-555. doi:10.1346/CCMN.1990.0380512.

[42] B.J. Lafferty, M. Ginder-Vogel, M. Zhu, K.J.T. Livi, D.L. Sparks, Arsenite oxidation by a poorly crystalline manganese-oxide. 2. results from X-ray absorption spectroscopy and X-ray diffraction, Environ. Sci. Technol. 44 (2010) 8467-8472. doi:10.1021/es102016c. 


\section{List of Table and Figure captions}

Table 1 Surface area, OVD concentration, specific As(III) oxidation rate, and initial $\mathrm{Mn}^{2+}$ production rate of the various birnessite morphologies.

Fig. 1. Change of $\mathrm{As}(\mathrm{III})$ concentration with reaction time in solution $(\mathrm{A})$ and the $r_{\mathrm{As}(\mathrm{V})}$ of birnessite samples (B). Reaction condition: $0.1 \mathrm{mmol} \mathrm{L}^{-1} \mathrm{As}(\mathrm{III})$ and $0.6 \mathrm{~g} \mathrm{~L}^{-1}$ birnessite at $\mathrm{pH}$ 6.0.

Fig. 2. Arsenite removal before and after addition of $0.1 \mathrm{mmol} \mathrm{L}^{-1} \mathrm{As}(\mathrm{V})(\mathrm{A})$, and $\mathrm{As}(\mathrm{V})$ adsorption on birnessite morphologies at pH 6.0 (B). Reaction time for As(III) oxidation is 30 min, initial As(V) concentration is $0.1 \mathrm{mmol} \mathrm{L}^{-1}$, birnessite concentration is $0.6 \mathrm{~g} \mathrm{~L}^{-1}, \mathrm{As}(\mathrm{V})$ adsorption equilibrium time is $24 \mathrm{~h}$.

Fig. 3. Arsenite removal before and after addition of $0.1 \mathrm{mmol} \mathrm{L}^{-1}$ phosphate (green column) and $\mathrm{Mn}^{2+}$ (blue column):Experimental condition: $0.1 \mathrm{mmol} \mathrm{L}^{-1} \mathrm{As}(\mathrm{III})$ and $0.6 \mathrm{~g} \mathrm{~L}^{-1}$ birnessite at $\mathrm{pH} 6.0$ (A) and the fitting result of phosphate adsorption kinetics on different birnessites (B): Experimental condition: initial phosphate concentration is $0.1 \mathrm{mmol} \mathrm{L}^{-1}$, birnessite dosage is $0.6 \mathrm{~g} \mathrm{~L}^{-1}, \mathrm{pH} 6.0$.

Fig. 4. Effect of phosphate concentration at $0.1,1$, and $4 \mathrm{mM}$ on $\mathrm{As}(\mathrm{III})$ removal on Bir-NF at pH 6.0 (A), and the fitting result of phosphate adsorption kinetics on Bir-NF at initial phosphate concentration of 0.1 and $4 \mathrm{mmol} \mathrm{L}^{-1}$ : Experimental conditions: birnessite dosage is $0.6 \mathrm{~g} \mathrm{~L}^{-1}, \mathrm{pH} 6.0$.

Fig. 5. Effect of initial As(III) concentration and Bir-NF concentrations (A) and (B) on As(III) removal at pH 6.0.

Fig. 6. Evolution of dissolved $\mathrm{Mn}^{2+}$ ions in solution during the reaction of $0.1 \mathrm{mmol} \mathrm{L}^{-1} \mathrm{As}(\mathrm{III})$ with $0.6 \mathrm{~g} \mathrm{~L}^{-1}$ birnessite at $\mathrm{pH} 6.0$.

Fig. 7. Evolution of dissolved $\mathrm{Mn}^{2+}$ ions in solution during the reaction of $0.1 \mathrm{mmol} \mathrm{L}^{-1} \mathrm{As}(\mathrm{III})$ with $0.6 \mathrm{~g} \mathrm{~L}^{-1}$ birnessite at $\mathrm{pH} 6.0$.

Fig. 8. Calculated slab of the $\{100\}$ birnessite surface with one $\mathrm{HAsO}_{3}{ }^{2-}$ ion adsorbed: the $\mathrm{H}_{2} \mathrm{O}$ molecule resides at the surface (a) and the oxygen vacancy site (b) of the slab. 
Table 1 Surface area, OVD concentration, specific As(III) oxidation rates, and initial $\mathrm{Mn}^{2+}$ production rate of birnessite samples.

\begin{tabular}{lccccc}
\hline Samples & $\begin{array}{c}\text { Surface area } \\
\left(\mathrm{m}^{2} \mathrm{~g}^{-1}\right)\end{array}$ & $\begin{array}{c}\text { Oxygen vacancy } \\
\text { defect concentration }\end{array}$ & $\begin{array}{c}\text { As(III) reaction rate } \\
\left(\mu \mathrm{mol} \mathrm{g}^{-1} \mathrm{~min}^{-1}\right)\end{array}$ & $\begin{array}{c}\text { Specific } \\
\text { rate }\left(\mu \mathrm{mol} \mathrm{m}^{-2} \mathrm{~min}^{-1}\right)\end{array}$ & $\begin{array}{c}r_{\mathrm{Mn} 2+} \\
\left(\mu \mathrm{mol} \mathrm{g}^{-1} \mathrm{~min}^{-1}\right)\end{array}$ \\
\hline Bir-NF & 162.6 & 0.39 & 24.7 & 0.15 & 27.0 \\
Bir-NW & 98.0 & 0.26 & 9.3 & 0.093 & 18.0 \\
Bir-NS & 19.0 & 0.08 & 1.4 & 0.083 & 3.3 \\
\hline
\end{tabular}

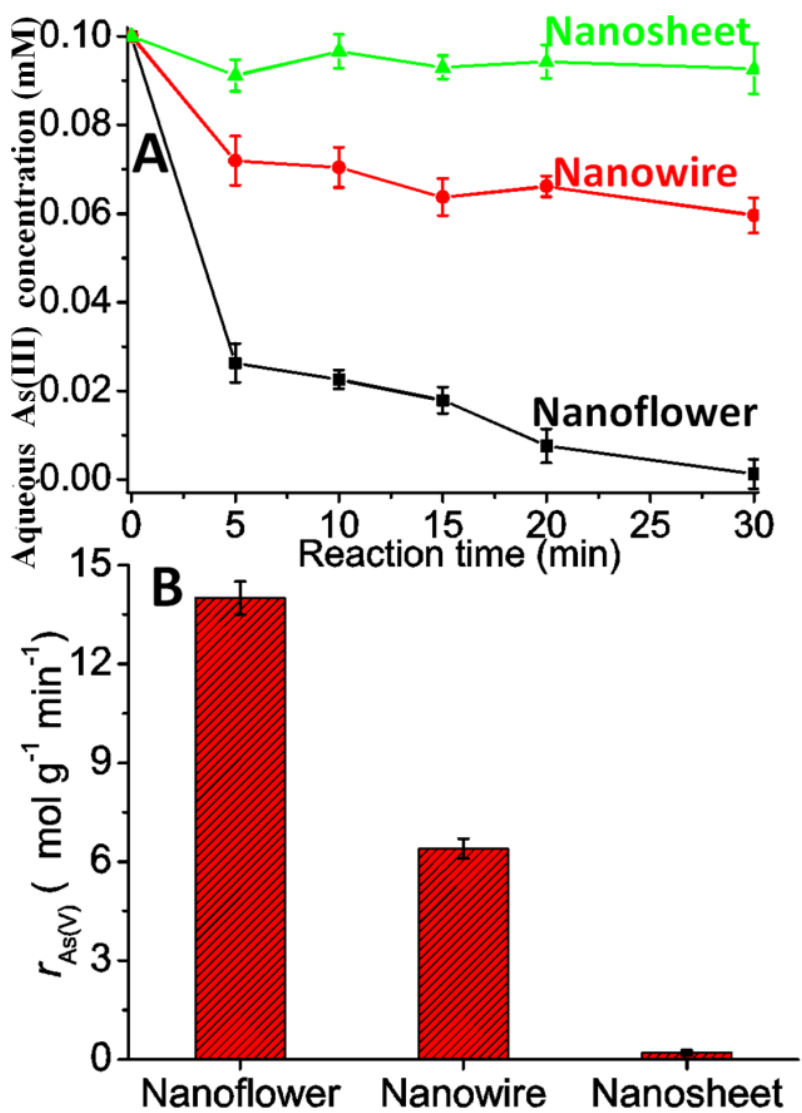

Fig. 1. Change of $\mathrm{As}(\mathrm{III})$ concentration with reaction time in solution $(\mathrm{A})$ and the $r_{\mathrm{As}(\mathrm{V})}$ of birnessite samples (B).

Reaction condition: $0.1 \mathrm{mmol} \mathrm{L}^{-1} \mathrm{As}(\mathrm{III})$ and $0.6 \mathrm{~g} \mathrm{~L}^{-1}$ birnessite at $\mathrm{pH}$ 6.0. 


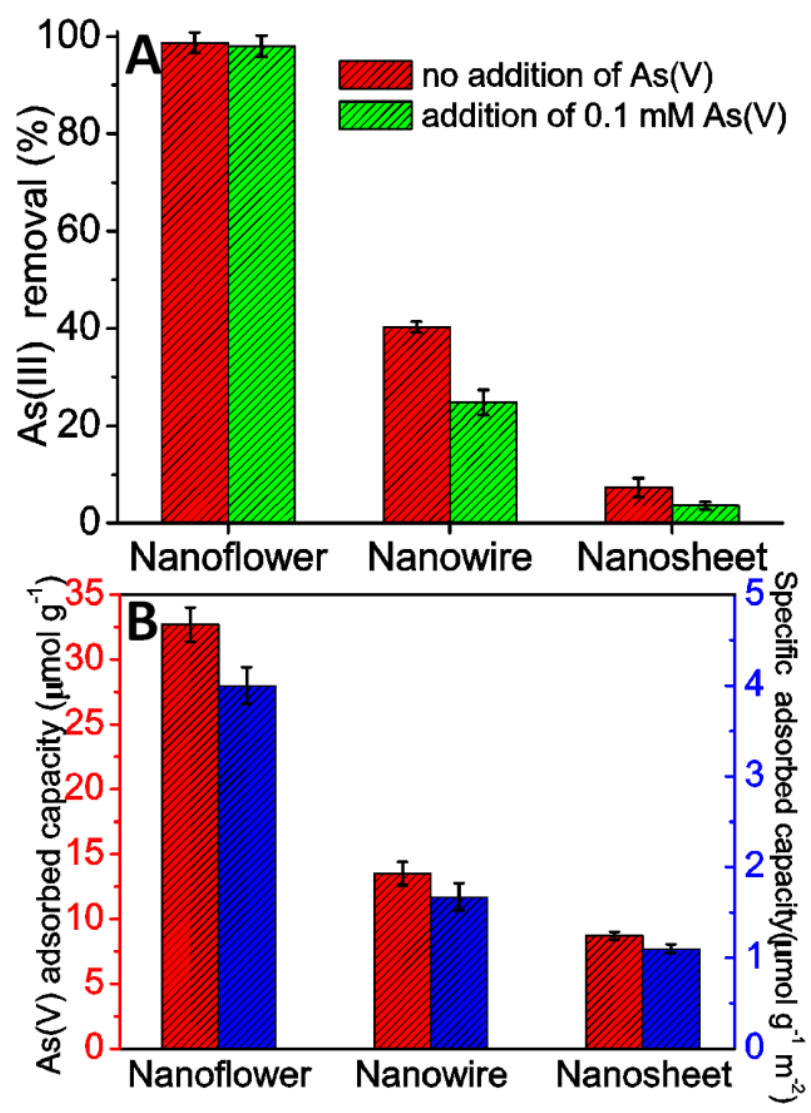

Fig. 2. Arsenite removal before and after addition of $0.1 \mathrm{mmol} \mathrm{L}^{-1} \mathrm{As}(\mathrm{V})(\mathrm{A})$, and $\mathrm{As}(\mathrm{V})$ adsorption on birnessite morphologies at pH 6.0 (B): Reaction time for As(III) oxidation is $30 \mathrm{~min}$, initial $\mathrm{As}(\mathrm{V})$ concentration is $0.1 \mathrm{mmol} \mathrm{L}^{-1}$, birnessite concentration is $0.6 \mathrm{~g} \mathrm{~L}^{-1}, \mathrm{As}(\mathrm{V})$ adsorption equilibrium time is $24 \mathrm{~h}$. 


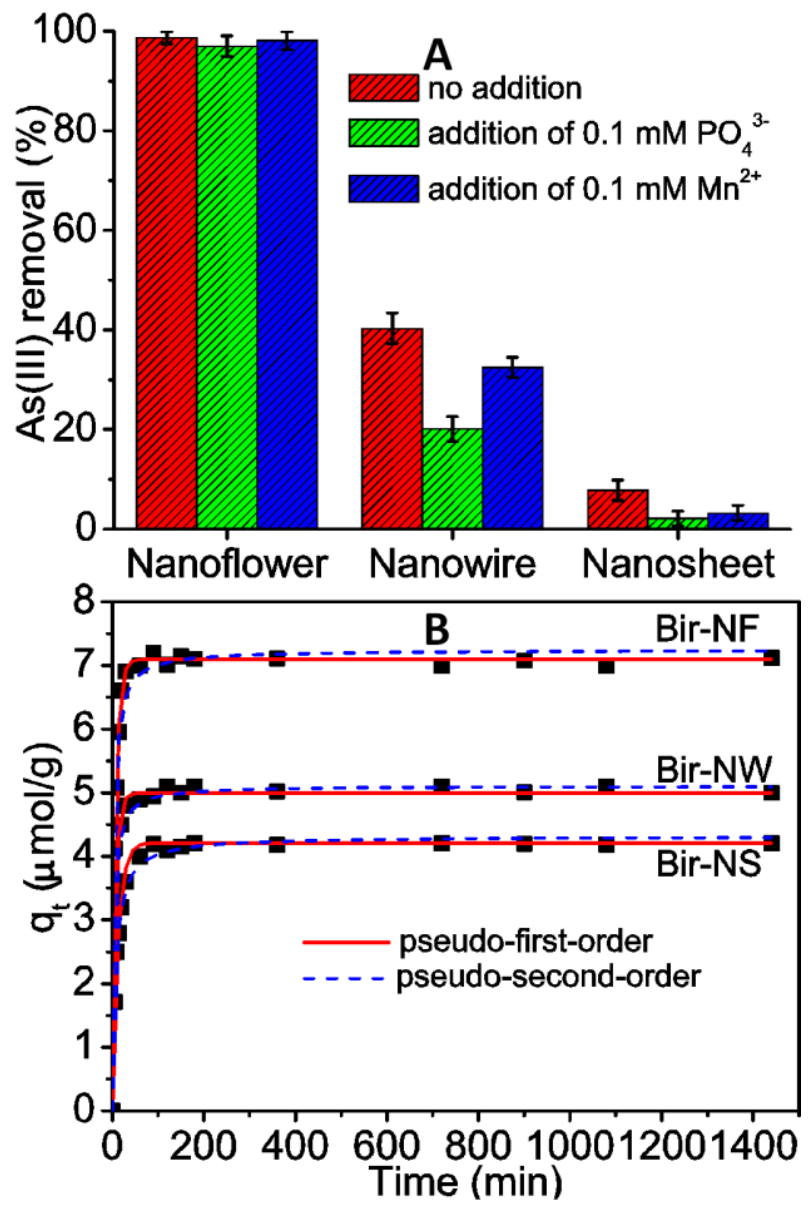

Fig. 3. Arsenite removal before and after addition of $0.1 \mathrm{mmol} \mathrm{L}^{-1}$ phosphate (green column) and $\mathrm{Mn}^{2+}(\mathrm{blue}$ column):

Experimental conditions: $0.1 \mathrm{mmol} \mathrm{L} \mathrm{m}^{-1} \mathrm{As}(\mathrm{III})$ and $0.6 \mathrm{~g} \mathrm{~L}^{-1}$ birnessite at $\mathrm{pH} 6.0(\mathrm{~A})$ and the fitting result of phosphate adsorption kinetics on different birnessites (B) Experimental condition: initial phosphate concentration is $0.1 \mathrm{mmol} \mathrm{L}^{-1}$, birnessite dosage is $0.6 \mathrm{~g} \mathrm{~L}^{-1}, \mathrm{pH} 6.0$. 


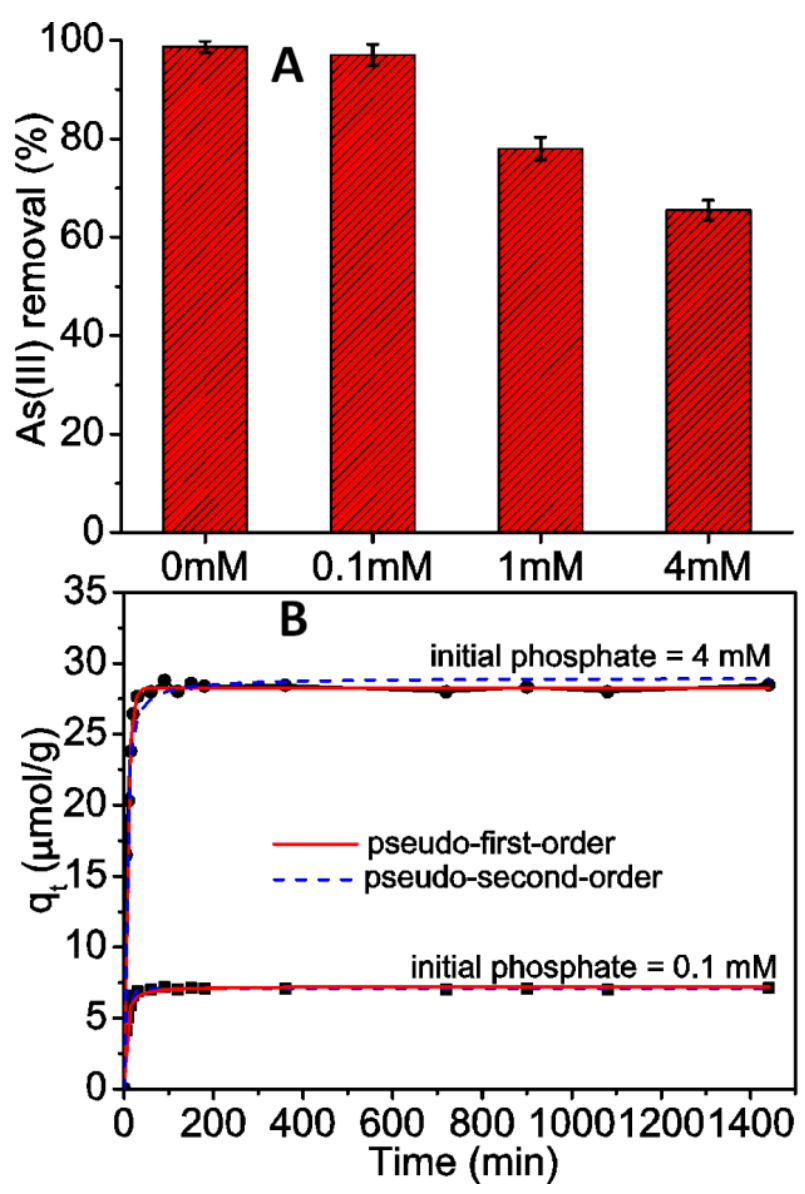

Fig. 4. Effect of phosphate concentration at $0.1,1$, and $4 \mathrm{mM}$ on $\mathrm{As}(\mathrm{III})$ removal on Bir-NF at pH 6.0 (A), and the fitting result of phosphate adsorption kinetics on Bir-NF at initial phosphate concentration of 0.1 and 4 mmol $\mathrm{L}^{-1}$ : Experimental conditions: birnessite dosage is $0.6 \mathrm{~g} \mathrm{~L}^{-1}, \mathrm{pH} 6.0$. 


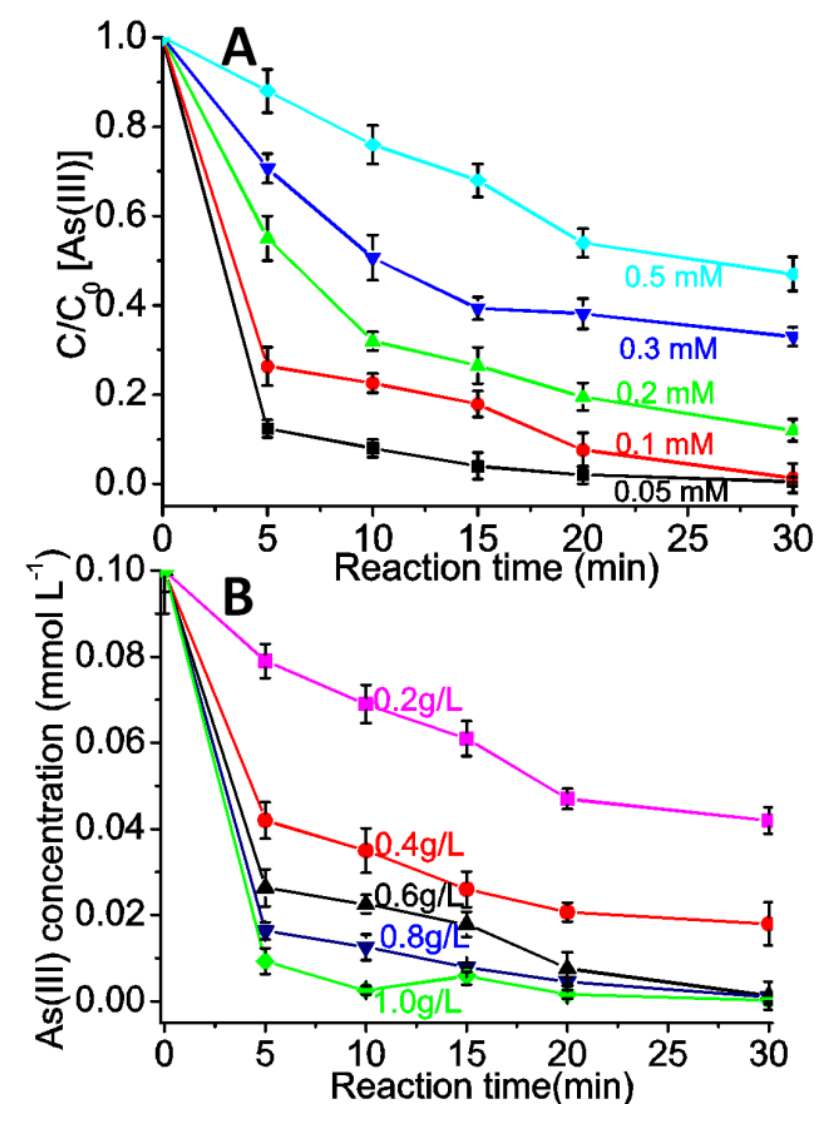

Fig. 5. Effect of initial As(III) concentration and Bir-NF concentrations (A) and (B) on As(III) removal at pH 6.0.

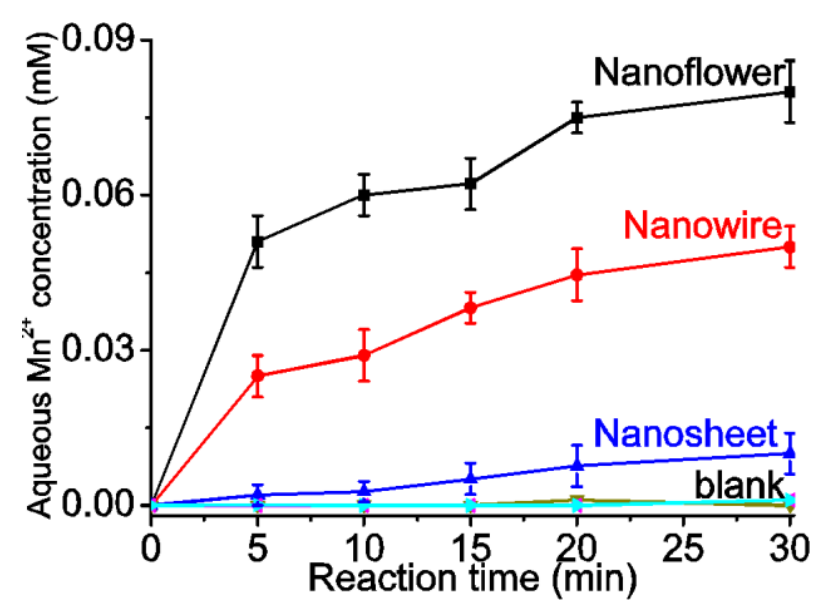

Fig. 6. Evolution of dissolved $\mathrm{Mn}^{2+}$ ions in solution during the reaction of $0.1 \mathrm{mmol} \mathrm{L}^{-1} \mathrm{As}(\mathrm{III})$ with $0.6 \mathrm{~g} \mathrm{~L}^{-1}$ birnessite at pH 6.0 (Cyan, magenta, and dark yellow lines represent blank tests of Bir-NF, Bir-NW, and Bir-NS samples in the absence of As(III), respectively.) 


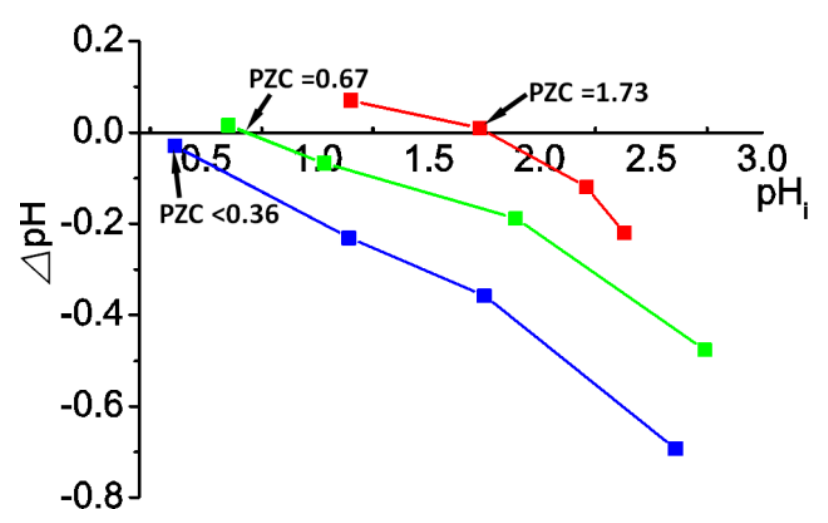

Fig. 7. Evolution of dissolved $\mathrm{Mn}^{2+}$ ions in solution during the reaction of $0.1 \mathrm{mmol} \mathrm{L}^{-1} \mathrm{As}(\mathrm{III})$ with $0.6 \mathrm{~g} \mathrm{~L}^{-1}$ birnessite at pH 6.0.

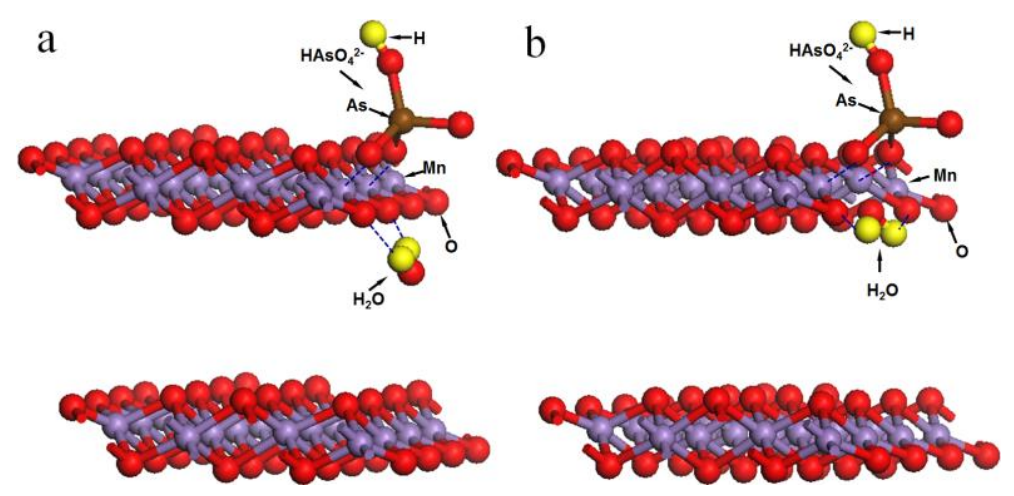

Fig. 8. Calculated slab of the $\{100\}$ birnessite surface with one $\mathrm{HAsO}_{3}{ }^{2-}$ ion adsorbed: the $\mathrm{H}_{2} \mathrm{O}$ molecule resides at the surface (a) and the oxygen vacancy site (b) of the slab. 


\section{Graphic Abstract:}

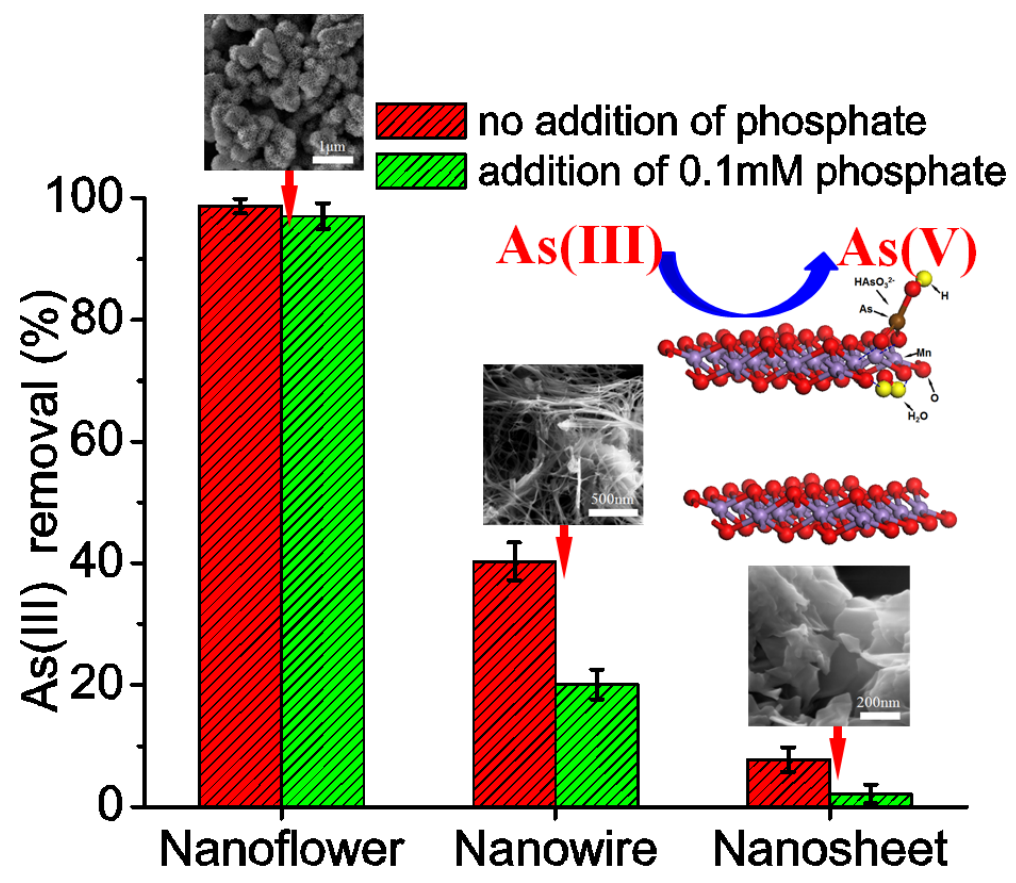

\section{Highlights}

$>$ As(III) oxidation performance of different birnessite morphologies was investigated.

$>$ Varying morphology from nanosheet to nanoflower significantly promotes As(III) oxidation activity of birnessites.

$>$ Origin of morphology effect on As(III) removal was experimentally and theoretically studied.

$>\quad$ Presence of high oxygen vacancy defect concentration makes adsorption of As(III) on birnessite more favorable.

$>$ Presence of high oxygen vacancy defect concentration in birnessite accelerates the charge transfer from As to Mn atoms. 


\section{Supporting Information}

\section{Morphology-Dependent Enhancement of Arsenite Oxidation to Arsenate on Birnessite-Type Manganese Oxide}

Jingtao Hou ${ }^{\mathrm{a}, \mathrm{b}, \mathrm{c}}$, Yongjin Xiang ${ }^{\mathrm{b}}$, Dan Zheng ${ }^{\mathrm{b}}$, Yuanzhi Li ${ }^{\mathrm{c}}$, Shengguo Xue d,e* , Chuan $\mathrm{Wu}^{\mathrm{d}, \mathrm{e}^{*}}$, William Hartley ${ }^{\mathrm{f}}$, Wenfeng Tan ${ }^{\text {a }}$

${ }^{\text {a }}$ College of Resources and Environment, Huazhong Agricultural University, Wuhan, 430070, China.

${ }^{\mathrm{b}}$ School of Environmental and Biological Engineering, Wuhan Technology and Business University, Wuhan, 430065, China.

${ }^{c}$ State Key Laboratory of Silicate Materials for Architectures Wuhan University of Technology, Wuhan, 430070, China.

${ }^{d}$ Department of Environmental Engineering, School of Metallurgy and Environment, Central South University, Changsha, 410083, China.

${ }^{\text {e }}$ Chinese National Engineering Research Centre for Control and Treatment of Heavy Metal Pollution, Changsha 410083, China

${ }^{\mathrm{f}}$ Crop and Environment Sciences Department, Harper Adams University, Newport, Shropshire, TF10 8NB, United Kingdom

Corresponding author:

*Email: sgxue70@hotmail.com (S. G. Xue),wuchuan@ csu.edu.cn (C. Wu).

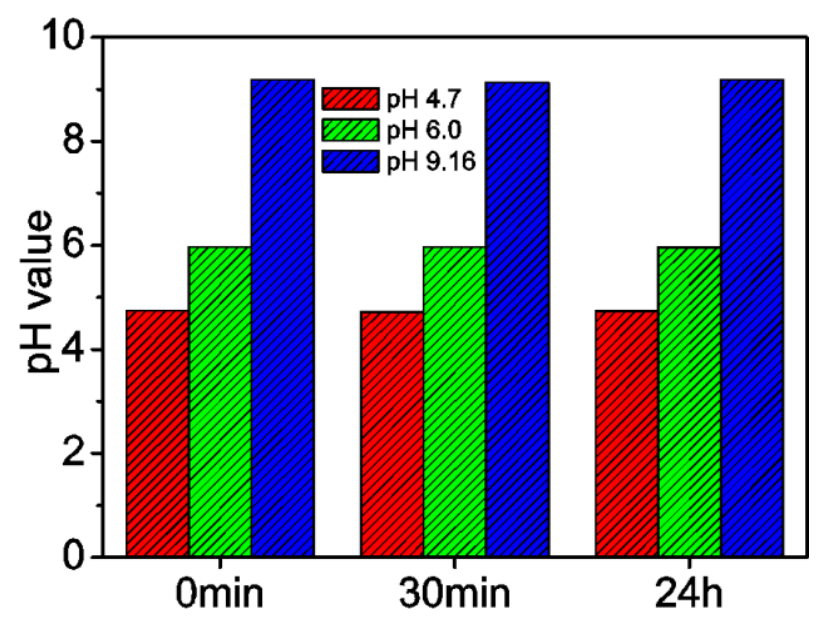

Fig. S1. Change of $\mathrm{pH}$ values in reaction period of $0 \mathrm{~min}, 30 \mathrm{~min}$, and $24 \mathrm{~h}$ for As(III) oxidation on Bir-NF sample at 


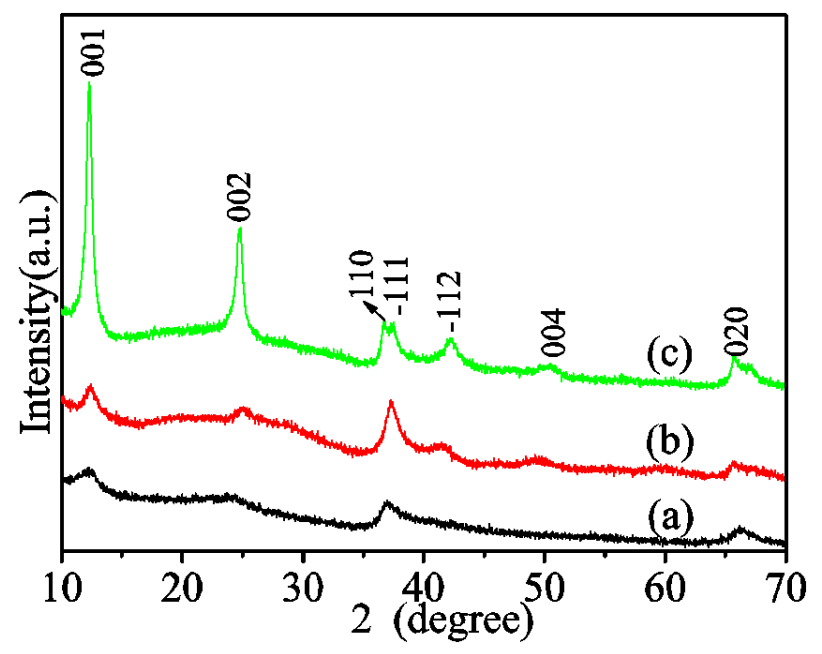

Fig. S2. XRD patterns of (a) Bir-NF, (b) Bir-NW, and (c) Bir-NS.

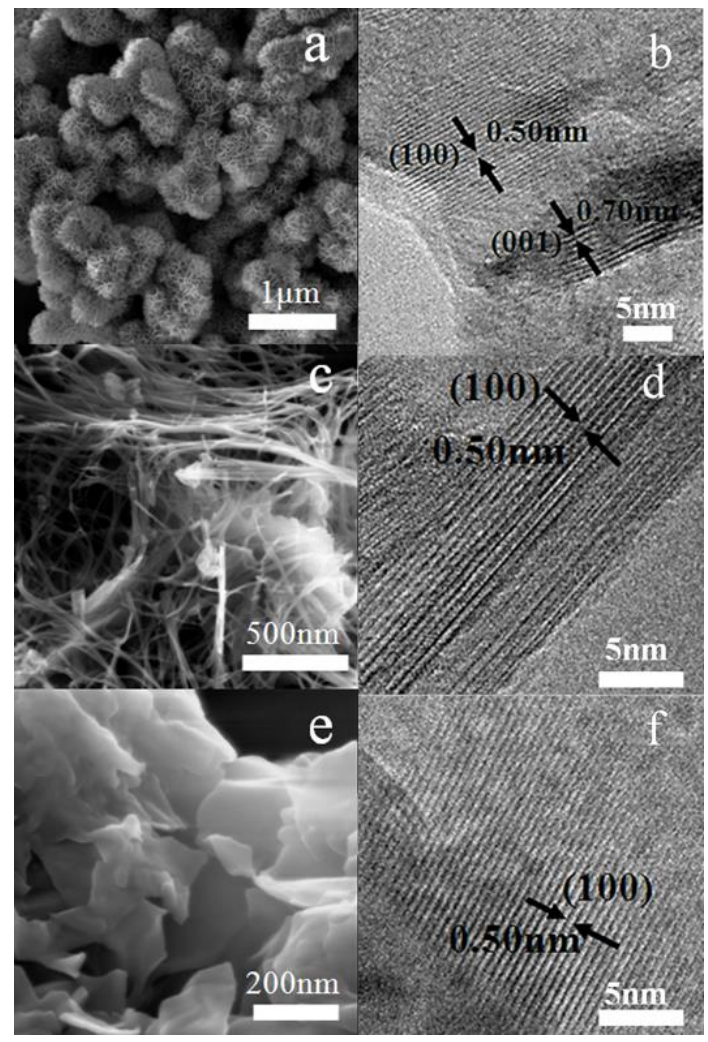

Fig. S3. FSEM and HRTEM images of nanoflower-like (a, b), nanowire-like (c, d), and nanosheet-like (e, f) birnessite samples. 


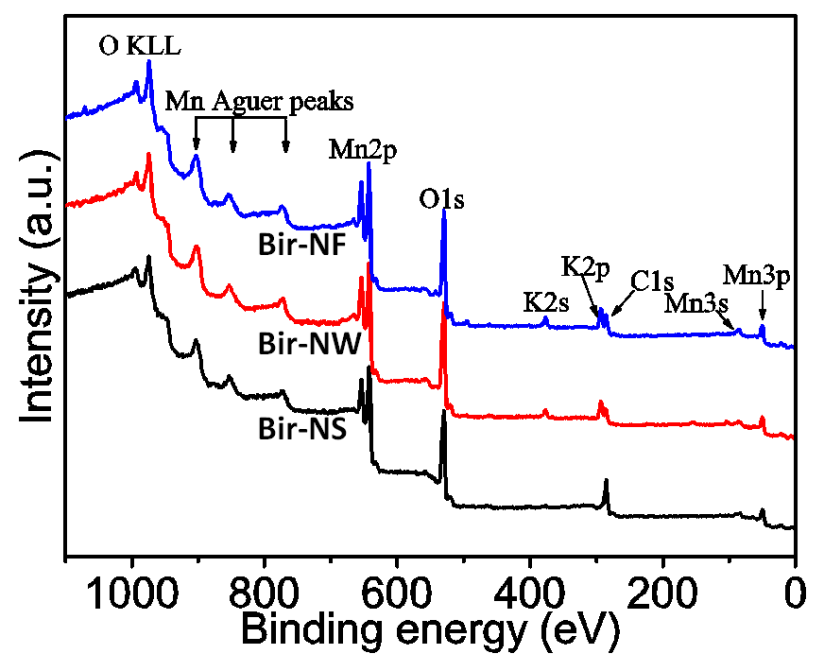

Fig. S4. XPS full spectra of birnessite samples.

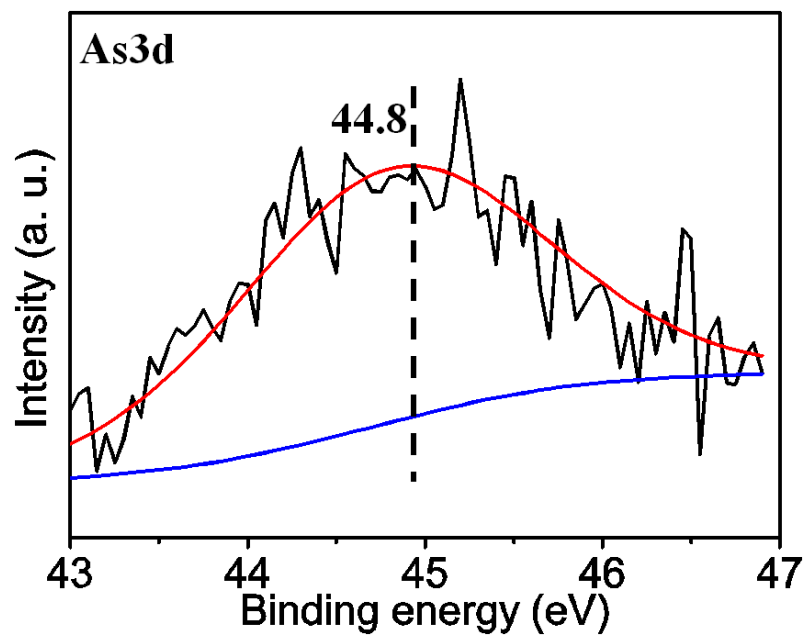

Fig. S5. As3d spectra of Bir-NF after reaction with $0.1 \mathrm{mM}$ As (III) solution.

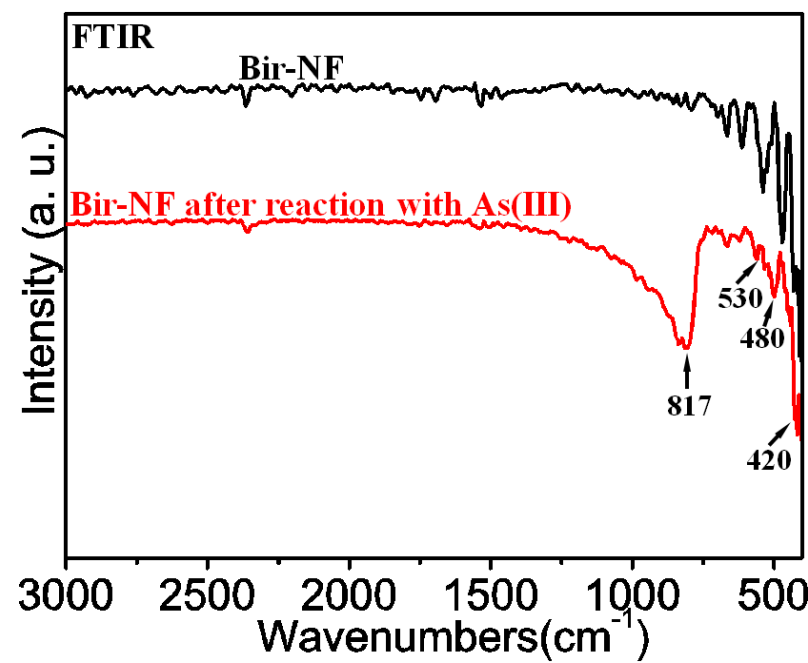

Fig. S6. FTIR spectra of Bir-NF before and after reaction with $0.1 \mathrm{mM}$ As (III) solution. 


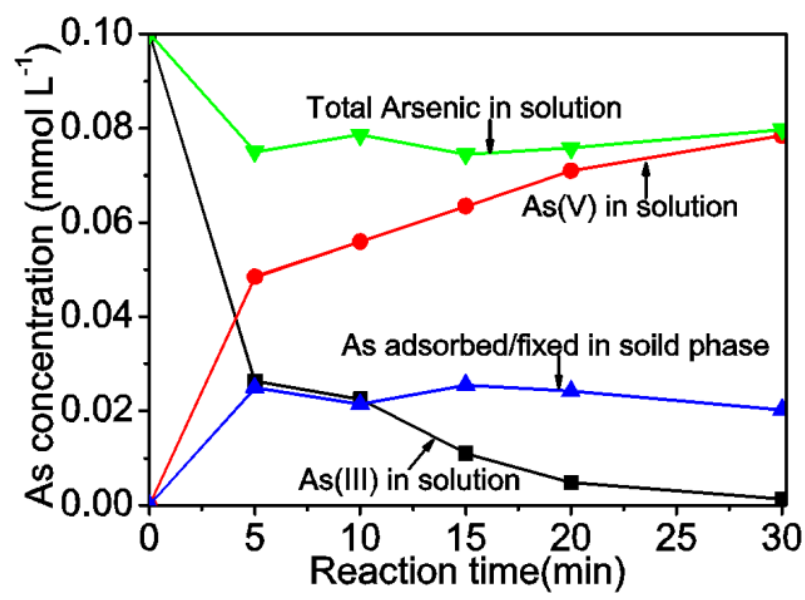

Fig. S7. Change in arsenic species concentration with reaction time in aqueous phase and solid phase.

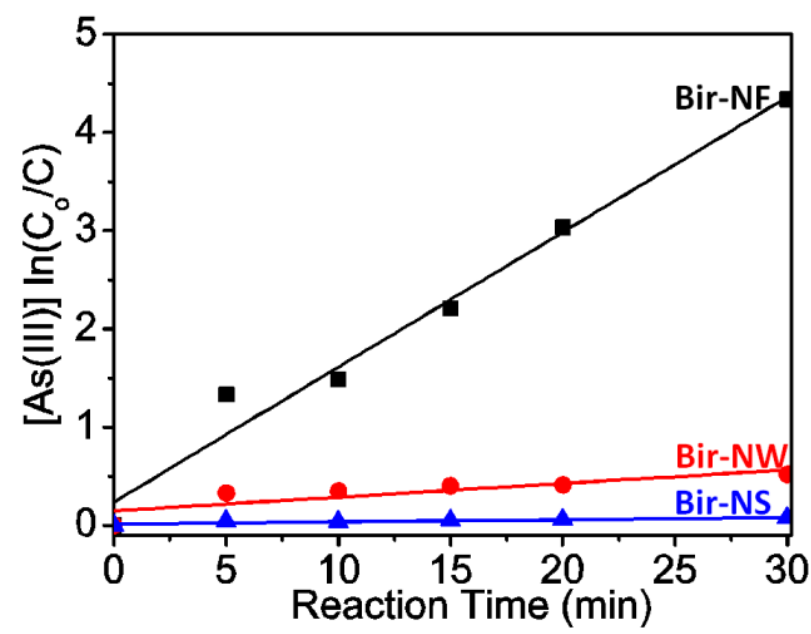

Fig. S8. The fitting result of As(III) oxidation on birnessites by a first-order kinetics equation at suspension density of $0.6 \mathrm{~g} \mathrm{~L}^{-1}$.

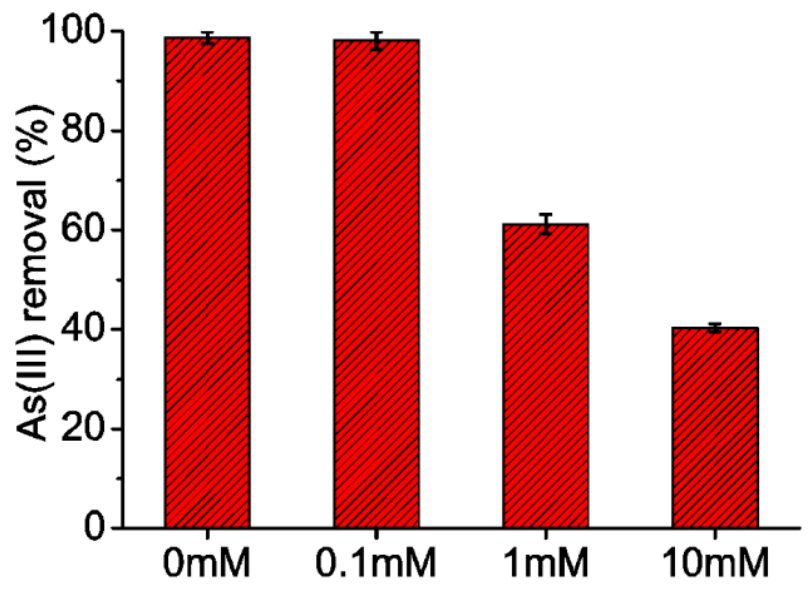

Fig. S9. Effect of $\mathrm{Mn}^{2+}$ concentration at $0.1,1$, and $4 \mathrm{mM}$ on $\mathrm{As}(\mathrm{III})$ removal on Bir-NF at pH 6.0: Experimental conditions: birnessite dosage is $0.6 \mathrm{~g} \mathrm{~L}^{-1}, \mathrm{pH} 6.0$. 
Table S1. Fitting parameters using pseudo-first order and pseudo-second-order models for phosphate adsorption on

different birnessite samples.

\begin{tabular}{ccccccc}
\hline Samples & \multicolumn{3}{c}{ pseudo-first-order } & \multicolumn{3}{c}{ pseudo-second-order } \\
\cline { 2 - 7 } & $k_{1}\left(\mathrm{~min}^{-1}\right)$ & $q_{e}(\mu \mathrm{mol} / \mathrm{g})$ & $R^{2}$ & $k_{2}\left(\mathrm{~g} \mu \mathrm{mol}^{-1} \mathrm{~min}^{-1}\right)$ & $q_{e}(\mu \mathrm{mol} / \mathrm{g})$ & $R^{2}$ \\
\hline Bir-NF & 0.130 & 7.1 & 0.9884 & 0.041 & 7.2 & 0.9860 \\
Bir-NW & 0.137 & 5.0 & 0.9395 & 0.056 & 5.1 & 0.9732 \\
Bir-NS & 0.080 & 4.2 & 0.9867 & 0.032 & 4.3 & 0.9936 \\
\hline
\end{tabular}

Table S2 Fitting parameters using pseudo-first order and pseudo-second-order models for phosphate adsorption on Bir-

NF at different initial concentrations.

\begin{tabular}{|c|c|c|c|c|c|c|}
\hline \multirow{2}{*}{$\begin{array}{c}\text { Initial } \\
\text { concentration } \\
\left(\mathrm{mmol} \mathrm{L}^{-1}\right)\end{array}$} & \multicolumn{3}{|c|}{ pseudo-first-order } & \multicolumn{3}{|c|}{ pseudo-second-order } \\
\hline & $k_{1}\left(\min ^{-1}\right)$ & $q_{e}(\mu \mathrm{mol} / \mathrm{g})$ & $R^{2}$ & $k_{2}\left(\mathrm{~g} \mu \mathrm{mol}^{-1} \mathrm{~min}^{-1}\right)$ & $q_{e}(\mu \mathrm{mol} / \mathrm{g})$ & $R^{2}$ \\
\hline 0.1 & 0.130 & 7.1 & 0.9884 & 0.041 & 7.2 & 0.9860 \\
\hline 4 & 0.138 & 28.3 & 0.9905 & 0.010 & 29.0 & 0.9855 \\
\hline
\end{tabular}

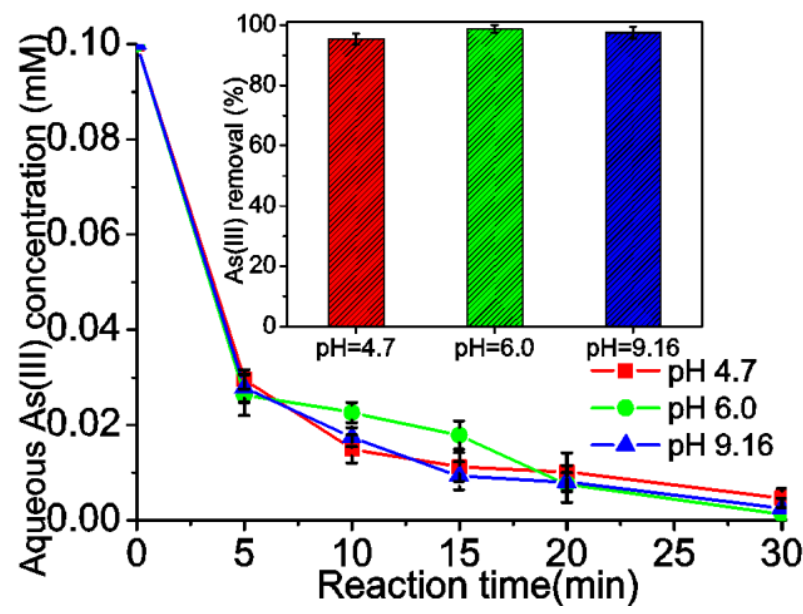

Fig. S10. Evolution of As(III) concentration during the reaction of $0.6 \mathrm{~g} \mathrm{~L}^{-1}$ Bir-NF at $\mathrm{pH} 4.7,6.0$, and 9.16 (inset in

Figure: Effect of $\mathrm{pH}$ on As(III) removal). 

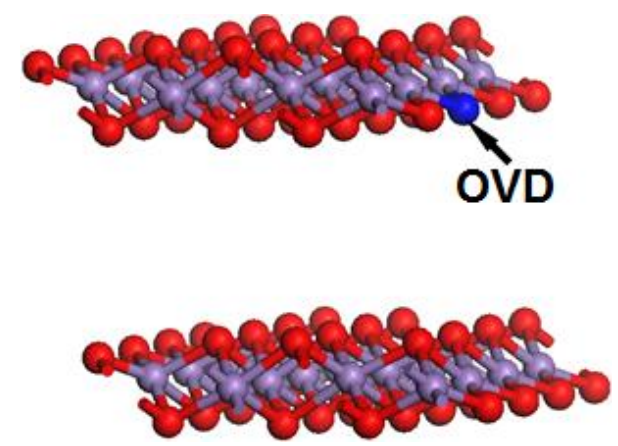

Fig. S11. The schematic diagram of OVD site on the slab of the $\{100\}$ birnessite surface: grey (Mn), red (oxygen), and blue (oxygen atom to be removed forming one OVD).

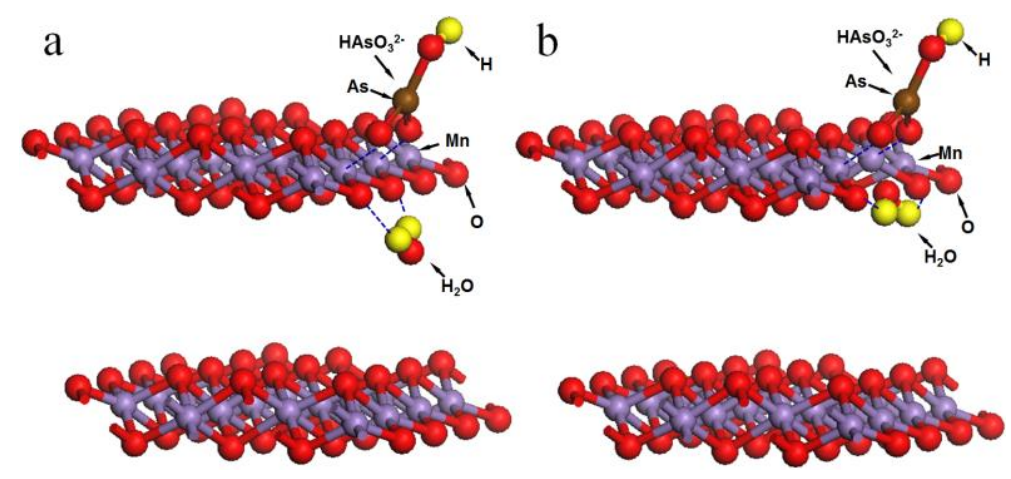

Fig. S12. Calculated slab of the $\{100\}$ birnessite surface with one $\mathrm{HAsO}_{4}{ }^{2-}$ ion adsorbed: the $\mathrm{H}_{2} \mathrm{O}$ molecule resides at the surface (a) and the oxygen vacancy site (b) of the slab. 